\title{
GEOLOGIC MAP OF SOUTHEASTERN ALASKA
}

\section{By}

\author{
George E. Gehrels and Henry C. Berg*
}

\section{INTRODUCTION}

Southeastern Alaska is underlain by Quaternary surficial deposits and by sedimentary, volcanic, intrusive, and metamorphic rocks ranging in age from Quaternary to Proterozoic(?). We have classified these rocks into map units on the basis of their age and lithic type, rather than their formally recognized names, in an effort to emphasize the regional distribution of lithically similar and generally coeval geologic units. The distribution, lithic components, age, stratigraphic or intrusive relations, and metamorphic and structural characteristics of the map units are described below in the Description of Map Units. The ages of map units are shown on the Correlation of Map Units, and the general lithic types of the units are listed in the Description of Map Units (see map sheet). Table 1 references all formally recognized geologic units in southeastern Alaska to our map units and to the geographic regions in which they are found.

Table 1. Formally recognized lithic units, their map symbols, and the geographic regions of southeast Alaska in which they are found.

\begin{tabular}{|c|c|c|}
\hline Formally recognized unit & Map symbol & Geographic region \\
\hline Admiralty Island Volcanics & TV & Admiralty Island \\
\hline Barlow Cove Formation & KPsv & Northern Admiralty Island \\
\hline Bay of Pillars Formation & Ss, Sc, Scg, SOsv & $\begin{array}{l}\text { Kuiu Island and nothern Prince or Wales } \\
\text { Island regions }\end{array}$ \\
\hline Black Cap Limestone & $\mathrm{Dc}$ & Glacier Bay region \\
\hline Bokan Mountain Granite & Jgr & Southern Prince of Wales Island \\
\hline Bowser Lake Group & JMsv & Coast Mountains \\
\hline Brothers Volcanics & KJv & Islands in southern Stephens Passage \\
\hline Burnt Island Conglomerate & ks & $\begin{array}{l}\text { Keku Straits area and west of Etolin } \\
\text { Island }\end{array}$ \\
\hline Cannery Formation & Ps, MDsv & Admiralty and Kupreanof Islands \\
\hline Cedar Cove Formation & Ds, Dc, Dcg & Eastern Chichagof Island \\
\hline Cenotaph Volcanics & Tv & West of Glacier Bay \\
\hline Chapin Peak Formation & kv & Gravina Island \\
\hline Cornwallis Limestone & $\mathrm{Kc}$ & Keku Straits area \\
\hline Coronados Volcanics & Dsv & Western Prince of Wales Island region \\
\hline Descon Formation & SOs, SOv, SOsv, SOsvc & Prince of Wales Island region \\
\hline Douglas Island Volcanics & KJv, KJsv & Juneau area \\
\hline Edgecumbe Volcanics & QTV & Kruzof Island \\
\hline Freeburn assemblage & Ksvm & Western Chichagof Island \\
\hline Freshwater Bay Formation & Dv & Western Chichagof Island \\
\hline Gambier Bay Formation & kOsv, kOc & Admiralty Island \\
\hline Goon Dip Greenstone & $\mathbf{k b}$ & Western Chichagof Island \\
\hline Gravina Island Formation & KJs, KJv & Gravina and Annette Islands \\
\hline Halleck Formation & Ps, Pv & Keku Straits area \\
\hline Hamilton Island Limestone & Kc & Keku Straits area \\
\hline
\end{tabular}

*Present addresses:

Géhrels: Department of Geosciences University of Arizona Tucson, Arizona 85721

Berg: 115 Malvern Ave. Fullerton, California 92632 
Table 1. Formally recognized lithic units, their map symbols, and the geographic regions of southeast Alaska in which they are found Continued.

\begin{tabular}{|c|c|c|}
\hline Formally recognized unit & Map symbol & Geographic region \\
\hline Hazelton Group & JMsv & Coast Mountains \\
\hline Heceta Limestone & $\mathrm{Sc}, \mathrm{Scg}$ & Prince of Wales Island region \\
\hline Hood Bay Formation & SOs & Southern Admiralty Island \\
\hline Hound Island Volcanics & kv & Keku Straits area \\
\hline Hyd Formation & Ksv, KPsv & Admiralty Island \\
\hline Hyd Group & Kv, Ksv, Kc & $\begin{array}{l}\text { Keku Straits and Annette and Gravina } \\
\text { Islands }\end{array}$ \\
\hline lyoukeen Formation & Mc & Eastern Chichagof Island \\
\hline Jualin Diorite & $J k d$ & Along east shore of Lynn Canal \\
\hline Karheen Formation & Ds, Dcg & $\begin{array}{l}\text { Annette and western Prince of Wales } \\
\text { Islands }\end{array}$ \\
\hline Keku Volcanics & KV & Keku Straits area \\
\hline Kelp Bay Group & Ksvm & Western Chichagof and Baranof Islands \\
\hline Kennel Creek Limestone & Sc, Scg & Eastern Chichagof Island \\
\hline Khaz Formation & Ksvm & Western Chichagof and Baranof Islands \\
\hline Klawak Formation & Ps & Western Prince of Wales Island region \\
\hline Kootznahoo Formation & Ts & Admiralty, Kuiu, and Zarembo Islands \\
\hline Kuiu Limestone & Sc, Scg & $\begin{array}{l}\text { Kuiu and northern Prince of Wales } \\
\text { Islands }\end{array}$ \\
\hline Ladrones Limestone & $\mathbb{P c}$ & Western Prince of Wales Islands region \\
\hline La Perouse gabbro & Tgb & West of Glacier Bay \\
\hline Nehenta Formation & Ksv & Gravina Island \\
\hline Peratrovich Formation & Mc & Western Prince of Wales Island region \\
\hline Pinnacle Peak Phyllite & Ksvm & Western Chichagof and Baranof Islands \\
\hline Point Augusta Formation & Sc, Ss & Eastern Chichagof Island \\
\hline Port Refugio Formation & Dv, Dsv & Western Prince of Wales Island region \\
\hline Puppets Formation & KV & Gravina Island \\
\hline Pybus Formation & $\mathrm{Pc}$ & $\begin{array}{l}\text { Keku Straits area, Admiralty Island, } \\
\text { and west of Etolin Island }\end{array}$ \\
\hline Pyramid Peak Limestone & $\mathrm{Sc}$ & Glacier Bay area \\
\hline Rendu Formation & DSsc & Glacier Bay area \\
\hline Retreat Group & kOsv & Admiralty Island \\
\hline Saginaw Bay Formation & PDsv & Keku Straits area \\
\hline Seymour Canal Formation & $\mathrm{KJ} s, \mathrm{KJV}$ & $\begin{array}{l}\text { Etolin-Kupreanof Islands, Admiralty } \\
\text { Island, and on mainland near Juneau } \\
\text { and Petersburg }\end{array}$ \\
\hline Shelter Formation & KJs, KJsv & Southern Lynn Canal \\
\hline Sitka Graywacke & Ks & Western Chichagof and Baranof Island \\
\hline Sloko Group & Tv & Coast Mountains northeast of Juneau \\
\hline St. Joseph Island Volcanics & Dsv & Western Prince of Wales Island region \\
\hline Stephens Passage Group & $\mathrm{KJ} s, \mathrm{KJv}, \mathrm{KJ} s \mathrm{v}$ & $\begin{array}{l}\text { Etolin-Kupreanof Islands, Admiralty } \\
\text { Island, and on mainland near Juneau } \\
\text { and Petersburg }\end{array}$ \\
\hline Texas Creek Granodiorite & $\mathrm{kg}$ & Coast Mountains northeast of Ketchikan \\
\hline Tidal Formation & Sc, Ss & Glacier Bay area \\
\hline Topsy Formation & Ts & West of Glacier Bay \\
\hline Treadwell Slate & KJs & Near Juneau \\
\hline Valdez Group & Ks, Kv, Ksv, & West of Glacier Bay \\
\hline Wadleigh Limestone & Dc & Western Prince of Wales Island region \\
\hline Wales Group & pOmsv,pOmc & Southern Prince of Wales Island region \\
\hline Waterfall Greenstone & Kvm & Western Chichagof Island \\
\hline Whitestripe Marble & Kc & Western Chichagof Island \\
\hline Willoughby Limestone & $\mathrm{Sc}$ & Glacier Bay area \\
\hline Yakataga Formation & QTs & West of Glacier Bay \\
\hline
\end{tabular}


The rocks of southeastern Alaska have been classified into four principle categories: (1) stratified rocks; (2) undivided stratified and (or) metamorphosed and (or) deformed rocks; (3) highly metamorphosed and (or) deformed rocks; and (4) intrusive rocks. The categories of units are defined as follows:

Units of the stratified rocks category consist of sedimentary and (or) volcanic rocks, and in some areas their regionally metamorphosed and (or) deformed equivalents, that generally conform to the Law of Superposition (North American Commission on Stratigraphic Nomenclature, 1983). Strata that belong to a particular unit in this category are generally similar in lithic type, stratigraphic position, and age of deposition and are, unless otherwise noted, interpreted to be generally correlative. Such strata generally constitute formations, lithic components of formations or groups, or unnamed geologic units of formation rank. An example of a unit of this type is $\mathrm{Sc}$, which includes Silurian carbonate rocks that (1) constitute the predominant rock type in the Heceta, Kuiu, Willoughby, and Pyramid Peak Limestones, and at least part of the Kennel Creek Limestone, (2) are a subordinate component in units composed predominantly of Silurian clastic strata (Bay of Pillars, Point Augusta, and Tidal Formations), and (3) belong to unnamed geologic units of formation rank.

Units of the undivided stratified and (or) metamorphosed and (or) deformed rocks category comprise stratified rocks and (or) their metamorphosed and (or) deformed equivalents that were not assigned to other categories of units because (1) their degree of deformation and (or) metamorphism are poorly known, (2) they are found in geologic units that grade from relatively intact stratigraphic sequences to metamorphic or structural units, or (3) they are known or interpreted to include two or more geologic units of formation rank that are not generally coeval. Most units of this category probably consist of, or were derived from, several stratified units of formation rank. These units are classified according to the probable minimum and maximum depositional age and the main lithic type of their constituent strata. An example of this type of map unit is $\mathbf{k}$ Osv, which consists of poorly known sedimentary and volcanic rocks of probable Triassic to Ordovician age that are stratified in some areas and are regionally metamorphosed and deformed in others.

Units of the highly metamorphosed and (or) deformed rocks category comprise rocks that were regionally metamorphosed and (or) deformed to a degree that their primary stratigraphic relations are not preserved (that is, the rocks do not conform to the Law of Superposition) (North American Commission on Stratigraphic Nomenclature, 1983). We assigned such rocks of southeastern Alaska to two types of units:

(1) Structural units, which consist of rocks that are deformed or disrupted to a degree that their primary stratigraphic relations are no longer preserved. Such units in southeastern Alaska constitute a melange (denoted by a lower case " $\mathrm{m}$ " at the end of the unit symbol) and a belt of regionally disrupted rocks (denoted by a lower-case " $\mathrm{d}$ " at the end of the unit symbol). Map units in the melange are classified according to the probable age of formation of the melange, rather than the depositional age of the constituent strata, and to the principle lithic type of the strata. The nature and age of the melange and of the rocks in each unit are discussed in the Description of Map Units. For example, unit Ksvm consists of sedimentary and volcanic rocks (and their deformed and metamorphosed equivalents) that belong to a melange that formed during Cretaceous time.

The belt of regionally disrupted rocks has some characteristics of a melange, but the stratigraphic and (or) structural relations between various lithic components of the belt are uncertain. Map units in this belt are classified according to the main lithic type and the probable age of deposition of the constituent strata. The nature and age of the belt and of the rocks in each unit are described in the Description of Map Units. For example, unit KDsd consists of clastic sedimentary rocks of Cretaceous through Devonian age that belong to a belt of strongly disrupted and deformed rocks.

(2) Metamorphic units, which comprise rocks in which primary stratigraphic relations were obliterated during regional metamorphism. Metamorphic units are classified according to the probable lithic type and depositional age of protoliths and are denoted by a lower case " $m$ " preceding the lithic term in the unit symbol. Their metamorphic rock types and the nature and age of metamorphism are discussed in the Description of Map Units. For example, unit pTmsv consists of metasedimentary and metavolcanic rocks (generally schist and gneiss) derived from pre-Tertiary sedimentary and volcanic rocks.

Units of the intrusive rocks category consist of intrusive rocks that are classified into map units according to their age of emplacement (following the Decade of North American Geology Geologic Time Scale (Palmer, 1983)), and to their predominant rock types (following the International Union of Geological Sciences classification scheme (Streckheisen, 1976)).

Areas in which intrusive rocks contain a significant component of country rock are shown by a stipple pattern on the geologic map. These types of mixed rocks are referred to as migmatites in some of the references cited below. Where country rock predominates over intrusive rock, the map unit corresponds to the country rock and the stipple pattern indicates that a significant proportion of the area is underlain by younger intrusive rock. For example, Triassic to Ordovician sedimentary and volcanic rocks ( $\mathrm{KOsv}$ ) on Admiralty Island are patterned where they contain a significant proportion of younger intrusive rock. Where younger intrusive rock predominates, the rocks are assigned to an intrusive unit and the stipple pattern indicates that a significant proportion of the area is underlain by older country rock. Intrusive unit TKg, for example, is patterned where Paleocene and Cretaceous granodiorite bodies contain abundant unmapped inclusions or pendants of pre-Tertiary metasedimentary and metavolcanic rocks elsewhere assigned to unit pTmsv. Some stippled intrusive rocks contain unmapped inclusions of country rock and are also intruded by younger igneous rocks. 


\section{ACKNOWLEDGMENTS}

We thank George Plafker, Travis Hudson, Earl Redman, E.C. Robertson, Chris Dodds, and J.B. Saleeby for allowing us to use their unpublished data, and George Plafker and R.L. Elliott for helpful comments on the map and text.

\section{DESCRIPTION OF MAP UNITS}

[See footnotes in Correlation of Map Units for restrictions on age designations]

Os

SURFICIAL DEPOSITS

Surficial sedimentary deposits (Quaternary)Unnamed lacustrine, fluvial, colluvial, glacial, beach, and marine deposits that are found in many areas of southeastern Alaska

\section{STRATIFIED ROCKS}

[May include metamorphosed and (or) deformed rocks]

QTV

Volcanic rocks (Quaternary and Tertiary)Edgecumbe Volcanics (basalt, andesite, and dacite) on Kruzof Island (Loney and others, 1975) and unnamed basaltic to rhyolitic rocks on islands west of Prince of Wales Island (Eberlein and others, 1983), on Revillagigedo Island and mainland to east (Berg and others, 1978, 1988), near Alaska-British Columbia border east of Wrangell Island (Elliott and Koch, 1981), and on Zarembo, Kuiu, and Kupreanof Islands (Brew and others, 1984). Rocks of Holocene age were recognized east of Wrangell Island (Elliott and others, 1981) and on Kruzof Island (Loney and others, 1975), and basaltic rocks of Holocene and (or) Pleistocene age are found on southern Kupreanof Island (Brew and others, 1984, 1985) and perhaps at other localities. Most volcanic rocks in this unit on Zarembo, Kupreanof, and Kuiu Islands are probably correlative with rocks in the Tertiary volcanic rocks unit (TV)

OTs Sedimentary rocks (Quaternary and Tertiary)-Pleistocene to Miocene marine mudstone, siltstone, sandstone, and conglomerate (Yakataga Formation) northwest of Cross Sound (Plafker and Addicott, 1976; George Plafker, written commun., 1984)

Tv Volcanic rocks (Tertiary)-Oligocene and Eocene basalt and andesite (Admiralty Island Volcanics) on Admiralty Island (Lathram and others, 1965); unnamed Oligocene basaltic rocks on islands in Icy Strait (Hudson and others, 1982); basaltic rocks (Cenotaph Volcanics) of Miocene and Oligocene age along coast northwest of Cross Sound (Brew and others, 1978); unnamed Pliocene(?) and Miocene(?) andesite in Glacier Bay (Brew and Ford, 1985); and andesitic to rhyolitic tuff and breccia (Sloko Group) of Eocene age northeast of Juneau (Brew and Ford, 1985; Souther, 1971). Volcanic rocks northwest of Cross Sound are interbedded with clastic strata belonging to the Topsy Formation (unit Ts) (Brew and others, 1978), and the Admiralty Island Volcanics contain clastic strata that may be in part correlative with the Kootznahoo Formation (unit Ts) (Lathram and others, 1965)

Sedimentary rocks (Tertiary)-Nonmarine sandstone, shale, and conglomerate (Kootznahoo Formation) in the ZaremboKuiu Islands region (Brew and others, 1984) and on Admiralty Island (Lathram and others, 1965), and marine calcareous sandstone and siltstone (Topsy Formation) of Miocene age northwest of Cross Sound (Brew and others, 1978; Marincovich, 1979). Age of the Kootznahoo Formation is reported to be Eocene and Paleocene in the Zarembo-Kuiu Islands region and Miocene to Eocene on Admiralty Island (Brew and others, 1984)

Tsv Sedimentary and volcanic rocks, undivided (Tertiary)-Unnamed carbonaceous shale, sandstone, and conglomerate of probable Paleogene age and subordinate Oligocene volcanic rocks near Haines (George Plafker, written commun., 1984; E.C. Robertson, written commun., 1984; Campbell and Dodds, 1983)

Ks Sedimentary rocks (Cretaceous)-Sandstone and mudstone turbidites and subordinate conglomerate (Sitka Graywacke) on Baranof, Chichagof, Kruzof, and Yakobi Islands (Loney and others, 1975; Johnson and Karl, 1985; Decker, 1980) and regionally metamorphosed carbonaceous siltstone, volcanogenic graywacke, mudstone, and minor conglomerate (Valdez Group) north of Cross Sound (Brew and others, 1978; George Plafker, written commun., 1984). Strata are interpreted to be deep-water marine trench, slope-basin, and fan deposits. The Sitka Graywacke is moderately deformed and disrupted, regionally metamorphosed as high as greenschist facies in some areas, and thermally upgraded to hornblende-hornfels facies locally (Decker and others, 1979; Johnson and Karl, 1985). Common rock types in metamorphosed regions south of Cross Sound include metagraywacke and argillite. Rocks north of Cross Sound are regionally metamorphosed from subgreenschist facies to as high as amphibolite facies, producing graywacke semischist, phyllite, slate, and layered schist, semischist, and gneiss (Brew and others, 
1978). These metasedimentary rocks are correlated with strata in the Valdez Group to northwest by lithic similarity (Brew and Morrell, 1979) and by stratigraphic continuity (Plafker and Campbell, 1979; Campbell and Dodds, 1983). Early Cretaceous fossils were found in the Sitka Graywacke on Kruzof Island (Reed and Coats, 1941); minimum age of these strata is constrained by Eocene granodiorite (Tgd) on Baranof Island (Loney and others, 1975). The Sitka Graywacke and rocks north of Cross Sound are considered to be Cretaceous in age on the basis of these constraints and correlation with lithically similar rocks in the Yakutat Group and Valdez Group (Plafker and others, 1977; Brew and Morrell, 1979)

Volcanic rocks (Cretaceous)-Basalt and basaltic tuff north of Cross Sound that are deformed and regionally metamorphosed as high as amphibolite facies (Brew and others, 1978; George Plafker, written commun., 1984). Common rock types include schist, gneiss, and amphibolite (Brew and others, 1978). Correlation with volcanic rocks in Valdez Group to northwest indicates a Cretaceous age (Plafker and Campbell, 1979; Brew and Morrell, 1979)

Ksv Sedimentary and volcanic rocks, undivided (Cretaceous)-Interbedded sedimentary and volcanic rocks, and their metamorphosed equivalents, that are correlative and continuous with Cretaceous sedimentary (Ks) and volcanic $(\mathrm{Kv})$ rocks. Found north of Cross Sound (Brew and others, 1978; Brew and Morrell, 1979; Plafker and Campbell, 1979). Age constraints, lithic types, metamorphic characteristics, and regional correlations are similar to those described above for Cretaceous sedimentary (Ks) and volcanic (Kv) rocks. Jurassic)-Marine graywacke and mudstone, subordinate conglomerate and andesitic to basaltic volcanic rocks, minor limestone, and regionally metamorphosed and deformed equivalents of these strata. Metamorphic grade generally increases from subgreenschist facies or nonmetamorphosed on southwest to greenschist and in some areas amphibolite facies to northeast. Rock types in higher grade parts of unit are primarily phyllite, schist, and gneiss. Strata are queried on geologic map where metamorphism and deformation, or lack of stratigraphic information, make correlation with sedimentary rocks of known Cretaceous and Jurassic age uncertain. Regional metamorphism and deformation occurred after Early Cretaceous time and prior to deposition of the Kootznahoo Formation

(unit Ts) of Miocene to Paleocene age (Buddington and Chapin, 1929). Fossils range in age from Cenomanian or Albian to Late and possibly Middle Jurassic (Berg and others, 1972; Brew and others, 1984). Unit consists of (1) the Gravina Island Formation and unnamed strata on Gravina Island (Berg and others, 1978, 1988); (2) unnamed strata on Annette Island, Revillagigedo Island, southern Etolin Island, and adjacent parts of mainland (Berg and others, 1978, 1988; Eberlein and others, 1983); (3) the Seymour Canal Formation (part of the Stephens Passage Group) and its metamorphic equivalents near Etolin and Kupreanof Islands and adjacent areas of mainland (Buddington and Chapin, 1929; Brew and others, 1984); (4) an unnamed unit of sandstone and mudstone in Keku Strait (Muffler, 1967); (5) the Seymour Canal Formation on Admiralty Island (Lathram and others, 1965), northern Kupreanof Island (Brew and others, 1984), and perhaps near Cape Fanshaw (Muffler, 1967; Buddington and Chapin, 1929); (6) the now-abandoned Symonds Formation (strata reassigned to the Seymour Canal Formation) and the Shelter Formation on islands in southern Lynn Canal (Barker, 1957; Brew and Ford, 1985); (7) the Treadwell Slate and unnamed strata near Juneau (Ford and Brew, 1973, 1977; Brew and Ford, 1985); (8) part of the nowabandoned Berners Formation (strata reassigned, in part, to the Seymour Canal Formation) northwest of Juneau (Knopf, 1911, 1912; Martin, 1926; Buddington and Chapin, 1929; Redman, 1984a; Brew and Ford, 1985); and (9) argillite, siltstone, and sandstone of probable Cretaceous and Jurassic age south of Haines (George Plafker, written commun., 1984)

KJsv Volcanic rocks (Cretaceous and Jurassic)Andesitic to basaltic flows, flow breccia, agglomerate, and tuff (generally containing conspicuous clinopyroxene phenocrysts), subordinate graywacke and mudstone, and regionally metamorphosed and deformed equivalents of these strata. Greenschist-facies metamorphism in some areas yielded common rock types of greenstone and greenschist. Age constrained by intertonguing stratigraphic relations with Cretaceous and Jurassic sedimentary rocks (KJs). Geologic and geochemical considerations suggest that some volcanic rocks in this unit are genetically related to Early Cretaceous ultramafic bodies (unit Kum) (Irvine, 1973, 1974) and possibly to Early Cretaceous and (or) Jurassic diorite (KJd) and gabbro (KJgb) (Berg and others, 
1978, 1988). Unit consists of (1) volcanic rocks (Gravina Island Formation) on Gravina Island (Berg and others, 1978, 1988); (2) unnamed rocks on Annette and Revillagigedo Islands and adjacent areas of mainland (Berg and others, 1978, 1988; Eberlein and others, 1983); (3) unnamed rocks in the Etolin-Kupreanof Islands region and adjacent areas of mainland (Brew and others, 1984; Buddington and Chapin, 1929); (4) the Douglas Island Volcanics and the Brothers Volcanics (part of Stephens Passage Group) on and near Admiralty Island (Lathram and others, 1965) and in the Juneau area (Ford and Brew, 1973, 1977; Brew and Ford, 1985); and (5) part of the now-abandoned Berners Formation (strata reassigned, in part, to the Douglas Island Volcanics) northwest of Juneau (Knopf, 1912; Martin, 1926; Brew and Ford, 1985)

KJsv Sedimentary and volcanic rocks, undivided (Cretaceous and Jurassic)-Moderately deformed and metamorphosed graywacke, mudstone, sandstone, and andesitic to basaltic rocks. Strata belong to the Shelter Formation in southern Lynn Canal (Barker, 1957) and are undifferentiated correlatives of the Treadwell Slate (unit KJs), the Seymour Canal Formation (unit KJs), and the Douglas Island Voicanics (unit KJv) near Juneau (Ford and Brew, 1973, 1977; Brew and Ford, 1985) conglomerate, limestone, and calcareous siltstone and sandstone (Burnt Island Conglomerate) west of Etolin Island (Karl, 1984) and on northwestern Kupreanof Island (Muffler, 1967); unnamed silty limestone of Late Triassic age on small islands between Etolin Island and northern Prince of Wales Island (Brew and others, 1984); and unnamed conglomerate and sedimentary breccia of probable Late Triassic age on east-central Prince of Wales Island (Buddington and Chapin, 1929; Eberlein and others, 1983; Gehrels and others, 1987)

$\mathrm{kV}$ Volcanic rocks (rhyolitic to basaltic) (Triassic)-Basaltic pillow flows, pillow breccia, and breccia; rhyolitic tuff with calcareous interbeds, flow breccia, and banded ash-flow tuff; and subordinate andesitic breccia and aquagene tuff. Rocks in most areas are moderately recrystallized and deformed. Fossils from interbedded rocks or from conformable adjacent strata indicate deposition during Norian and Carnian time. Unit consists of (1) rhyolite (part of the Hyd Group) on Annette Island (Berg, 1982; Gehrels and others, 1987); (2) rhyolite (Puppets Formation; part of the Hyd Group) and basalt (Chapin Peak Formation; part of the Hyd Group) on Gravina Island (Berg, 1982; Berg and others, 1978, 1988; Gehrels and others, 1986, 1987); and (3) rhyolite and subordinate basait (Keku Volcanics) and basalt and andesite (Hound Island Volcanics; part of the Hyd Group) in Keku Strait (Muffler, 1967; Brew and others, 1984)

Ksv Sedimentary and volcanic rocks, undivided (Triassic)—Black shale, shaly limestone, siltstone, sandstone, conglomerate, and limestone; felsic, intermediate, and mafic flows; and minor black chert. Rocks vary from relatively unmetamorphosed to as high as greenschist facies. Common rock types in higher grade areas include phyllite, slate, semischist, marble, greenschist, and greenstone. Unit consists of (1) the Nehenta Formation and other strata (parts of the Hyd Group) on Annette and Gravina Islands (Berg and others, 1978, 1988; Gehrels and others, 1987); (2) unnamed strata in the belt of disrupted rocks (units KDsd and KDvd) on Kupreanof and Zarembo Islands (Brew, 1982; Brew and others, 1984; Berg and Grybeck, 1980; McClelland and Gehrels, 1987); and (3) the part of the Hyd Formation (Hyd Group of Muffler, 1967, in Keku Islet area) on Admiralty Island that was reliably separated from the Cannery Formation (unit Ps) (Lathram and others, 1965)

Kc Carbonate rocks (Triassic)-Massive to thickbedded limestone and minor dolomite in most areas, but in Keku Strait unit includes thin-bedded, dark-gray limestone, and on Chichagof Island unit consists of massive white to gray marble (Whitestripe Marble). Diagnostic fossils from limestone and dolomite are Late Triassic in age. Marble on Chichagof Island is assigned a Triassic(?) age by Loney and others (1975), but is interpreted by Plafker and others (1976) and Jones and others (1977) to be Late Triassic by correlation with the Chitistone Limestone in the Wrangell Mountains of southern Alaska. Plafker and others (1976) and Jones and others (1977) also suggest that the Whitestripe Marble is not correlative with other carbonate rocks included in this unit. Unit consists of (1) limestone and marble (parts of the Hyd Group) on Annette and Gravina Islands (Berg and others, 1978, 1988; Berg, 1982; Gehrels and others, 1987); (2) the Cornwallis Limestone and Hamilton Island Limestone (parts of the Hyd Group) on northern Kuiu and Kupreanof Islands (Muffler, 1967; Brew and others, 1984); and (3) the Whitestripe Marble on Chichagof Island (Loney and others, 1975; 
Johnson and Karl, 1985)

Kb Basaltic rocks (Triassic)-Basaltic flows and flow breccia (Goon Dip Greenstone) on Chichagof and Yakobi Islands that were deposited, at least in part, in subaerial environments (Loney and others, 1975; Johnson and Karl, 1985) and unnamed basalt near Haines (Plafker and Hudson, 1980; Redman and others, 1984; E.C. Robertson, written commun., 1984; Davis and Plaiker, 1985). The Goon Dip Greenstone is assigned a Triassic(?) age by Loney and others (1975), but Plafker and others (1976) and Jones and others (1977) suggest that the Goon Dip Greenstone is probably correlative with the Upper and (or) Middle Triassic Nikolai Greenstone in the Wrangell Mountains of southern Alaska. Basalt near Haines yields Carnian fossils and is also interpreted by Davis and Plafker (1985) to be correlative with the Nikolai Greenstone

Clastic sedimentary and carbonate rocks, undivided (Triassic)_Unnamed, moderately deformed and metamorphosed graphitic limestone and slate of late Ladinian (latest Middle Triassic) age on Revillagigedo Island (Silberling and others, 1982). On the basis of regional stratigraphic relations and slightly older age, Silberling and others (1982) and Berg and others (1972) suggest that these strata are not correlative with strata assigned to other Triassic units (unitsks, kc, and Ksv)

Sedimentary rocks (Permian)_Black argillite, graywacke, calcareous siltstone, chert, and minor basaltic rocks, limestone, and conglomerate. Unit consists of (1) part of the Halleck Formation of Early Permian age near Keku Strait (Muffler, 1967; Brew and others, 1984; Jones and others, 1981); (2) the Cannery Formation on southern Admiralty Island (reported to be Early Permian in age, Lathram and others, 1965); and (3) unnamed Permian strata northeast of Glacier Bay (Brew and others, 1978). Strata locally metamorphosed to slate and phyllite

Volcanic rocks (Permian)_Lower Permian basalt (part of the Halleck Formation) on northern Kuiu Island (Muffler, 1967) and unnamed Permian basaltic(?) rocks northeast of Glacier Bay (Brew and others, 1978). Age constrained by interbedded Lower Permian clastic strata (unit Ps) on Kuiu Island and interbedded Permian carbonate rocks $(\mathrm{Pc})$ in Glacier Bay area

Carbonate rocks (Permian) - Consists of (1) greenschist-facies, massive to thin-bedded marble of Early Permian age on Revillagigedo Island (Silberling and others, 1982; Berg and others, 1978, 1988) and of Permian(?) age on mainland east of Admiralty Island (Brew and Grybeck, 1984); (2) medium-bedded dolomite, limestone, and subordinate gray chert beds and nodules (Pybus Formation) on northern Kuiu and Kupreanof Islands (Lower Permian) (Muffler, 1967; Brew and others, 1984), Admiralty Island (Permian) (Lathram and others, 1965), and a small island between northern Prince of Wales and Etolin Island (Lower Permian) (Brew and others, 1984); and (3) unnamed fossiliferous gray limestone, cherty limestone, and limestone conglomerate of Permian age northeast of Glacier Bay (Brew and others, 1978) and along west shore of Lynn Canal (Lathram and others, 1959; Brew and Ford, 1985). Marble on Revillagigedo Island and on mainland east of Admiralty Island may not be correlative with Permian carbonate rocks elsewhere in map area (Silberling and others, 1982)

Ps Sedimentary rocks (Pennsylvanian)--Middle and Lower Pennsylvanian sandstone and siltstone containing minor limestone and chert-pebble conglomerate (Klawak Formation). Unit found on west-central Prince of Wales Island (Eberlein and others, 1983)

Pc Carbonate rocks (Pennsylvanian)-Massive limestone and minor dolomite containing light-gray chert nodules (Ladrones Limestone) on west-central Prince of Wales Island (Eberlein and others, 1983) and unnamed, medium-bedded to massive crinoidal limestone on northern Kuiu Island (Brew and others, 1984). Fossils indicate deposition during Middle and Early Pennsylvanian time

Mc Carbonate rocks (Mississippian)-Thin- to thick-bedded, dark-gray limestone, subordinate beds and nodules of light-gray chert, and minor shale and gypsum. Unit consists of the Peratrovich Formation on western Prince of Wales Island (Eberlein and others, 1983) and the lyoukeen Formation on Chichagof Island (Loney and others, 1975). Strata deposited during Late and Early Mississippian time

MDsv Sedimentary and volcanic rocks, undivided (Mississippian and Devonian)-Tuffaceous argillite and graywacke and subordinate chert, limestone, and andesitic volcanic rocks (Cannery Formation) on northern Kupreanof Island (Muffler, 1967; Brew and others, 1984). Fossils are Late Devonian and Early and Late Mississippian in age (Jones and others, 1981)

Ds Sedimentary rocks (Devonian)-Siltstone, shale, sandstone, graywacke, and subordinate limestone breccia, arkose, conglomerate, and volcanic rocks. Unit 
consists of (1) the Lower Devonian Karheen Formation in the Annette-Gravina Islands area (Gehrels and others, 1987) and on southern Prince of Wales Island (Herreid and others, 1978; Gehrels and Saleeby, 1986, 1987a; Savage and Gehrels, 1984); (2) unnamed Lower Devonian strata on westcentral Prince of Wales Island and on smaller islands to west (Eberlein and others, 1983); (3) unnamed Devonian(?) graywacke, argillite, and arkose on northern Kuiu Island (Brew and others, 1984); and (4) undivided part of the Devonian Cedar Cove Formation on northeastern Chichagof Island (Loney and others, 1975)

Volcanic rocks (Devonian)-Basaltic and subordinate andesitic pillow flows, breccia, aquagene tuff, and minor sedimentary interbeds. Unit consists of (1) unnamed basaltic-andesitic pillow flows and breccia (Lower Devonian) on small islands south of Annette Island (Gehrels and others, 1987) and on southern Prince of Wales Island (Herreid and others, 1978; Gehrels and Saleeby, 1986, 1987a); (2) basaltic rocks in the Port Refugio Formation (Upper Devonian) on west-central Prince of Wales Island (Eberlein and others, 1983); (3) Lower Devonian rhyolite in Kasaan Bay on east-central Prince of Wales Island (Eberlein and others, 1983; Savage, 1981); and (4) Upper Devonian andesite, basalt, and minor rhyolite (Freshwater Bay Formation) on Chichagof Island (Loney and others, 1975)

Sedimentary and volcanic rocks, undivided (Devonian)-Siltstone, shale, volcanogenic graywacke, conglomerate, and minor limestone that are interbedded with basaltic pillow flows, breccia, and aquagene tuff. Unit consists of the Coronados Volcanics (Devonian), the Devonian(?) St. Joseph Island Volcanics, and part of the Upper Devonian Port Refugio Formation, all of which are found on western Prince of Wales Island and adjacent islands (Eberlein and others, 1983)

Dc Carbonate rocks (Devonian)-Thin-bedded to massive, gray limestone and minor shale interbeds. Unit consists of (1) the Upper and Middle (and probably upper Lower) Devonian Wadleigh Limestone in westcentral Prince of Wales Island region (Eberlein and others, 1983; Savage and Gehrels, 1984); (2) unnamed Lower Devonian limestone on east-central Prince of Wales Island (Eberlein and others, 1983); (3) unnamed Middle and Lower Devonian limestone and marble in belt of disrupted rocks (units KDsd and KDvd) on Kupreanof Island (Brew, 1982; Brew and others, 1984; McClelland and Gehrels, 1987); (4) upper part of the Cedar Cove Formation (Upper and Middle Devonian) on Chichagof Island (Loney and others, 1975); (5) the Black Cap Limestone (Middle Devonian) in Glacier Bay (Rossman, 1963; Brew and others, 1978); and (6) strata correlative with the Black Cap Limestone in Chilkat Range and along west shore of Lynn Canal (Lathram and others, 1959; Loney and others, 1975; Brew and Ford, 1985)

Dcg Conglomeratic rocks (Devonian)-Conglomerate and sedimentary breccia interbedded with sandstone, siltstone, shale, and minor graywacke, limestone, and volcanic rocks. Sedimentary structures and presence of red beds and thick sections of coarse conglomerate suggest that strata in Prince of Wales Island region were deposited in subaerial to shallow-water marine environments (Ovenshine, 1975; Gehrels and Saleeby, 1987a). Strata on Chichagof Island were probably also deposited in a shallow-water marine environment (Loney and others, 1975). Unit consists of the Lower Devonian Karheen Formation on southern Prince of Wales Island (Gehrels and Saleeby, 1986, 1987a) and on central Prince of Wales Island (Eberlein and others, 1983), and conglomeratic rocks in the Cedar Cove Formation on Chichagof Island (Loney and others, 1975) that we interpret to be generally correlative with the Lower Devonian Karheen Formation

Sc Carbonate rocks (Silurian)-Massive, thin- to thick-bedded, locally reefoidal, light-gray limestone and subordinate shale and polymictic conglomerate. Unit consists of (1) unnamed Silurian limestone and marble on Dall and Long Islands (Eberlein and others, 1983; Gehrels and Saleeby, 1987b; G.E. Gehrels, unpub. data, 1984); (2) part of the Upper and Lower Silurian Heceta Limestone on Prince of Wales Island (Eberlein and others, 1983; Brew and others, 1984); (3) the Upper Silurian Kuiu Limestone and limestone layers in the Upper and Lower Silurian Bay of Pillars Formation on Kuiu Island (Muffler, 1967; Brew and others, 1984); (4) the Kennel Creek Limestone (Devonian and (or) Silurian; the Silurian age is favored by Loney and others, 1975) and limestone layers in the Upper(?) Silurian Point Augusta Formation on Chichagof Island (Loney and others, 1975); (5) the Willoughby Limestone, Pyramid Peak Limestone, and limestone layers in the Tidal Formation (all considered to be Silurian by Rossman, 1963) in the Glacier Bay area (Rossman, 1963; Brew and others, 1978); and (6) unnamed Devonian and Silurian(?) limestone in Chilkat Range (Lathram and 
others, 1959; Brew and Ford, 1985). Loney and others (1975) report that limestone in the Chilkat Range is lithically similar to the Kennel Creek Limestone and contains similar fossils. On the basis of these observations and apparent similarity in stratigraphic position, we interpret limestone in "limestone and marble" and "siliceous argillite and volcanic" units of Lathram and others (1959) to be correlative with the Kennel Creek Limestone and limestone layers in the Point Augusta Formation on Chichagof Island. Although stratigraphic relations and fossils indicate that most strata in unit are Silurian in age, deposition of strata in some areas possibly continued into Early Devonian time

Conglomeratic rocks (Silurian)-Polymictic pebble and cobble conglomerate and subordinate sedimentary breccia, olistostromal deposits, sandstone, graywacke, mudstone, and limestone. Clasts consist of porphyritic andesite, limestone, graywacke, mudstone, granitic to gabbroic intrusive rocks, chert, and other rocks derived from various pre-Devonian units. Unit consists of layers and lenses of polymictic conglomerate in (1) unnamed units on northern Prince of Wales Island (Brew and others, 1984); (2) the Heceta Limestone (unit $\mathrm{Sc}$ ) and the Bay of Pillars Formation (unit Ss) on central and northern Prince of Wales Island (Eberlein and others, 1983; Brew and others, 1984);

(3) the Kuiu Limestone (unit Sc) and the Bay of Pillars Formation on Kuiu Island (Brew and others, 1984); and (4) the Kennel Creek Limestone (unit $\mathrm{Sc}$ ) on Chichagof Island (Loney and others, 1975)

Sedimentary rocks (Silurian)-Graywacke and mudstone turbidites and subordinate olistostromal deposits, layers and lenses of limestone, and conglomerate. Unit consists of (1) most of the Bay of Pillars Formation (Upper and Lower Silurian) on northern Prince of Wales Island and Kuiu Island (Brew and others, 1984); (2) the Upper(?) Silurian Point Augusta Formation on Chichagof Island (Loney and others, 1975); (3) the Upper Silurian Tidal Formation in Glacier Bay (Rossman, 1963; Brew and others, 1978); and (4) clastic sedimentary rocks belonging to the Devonian and Silurian(?) units of Lathram and others (1959) in the Chilkat Range (interpreted to be Upper Silurian by Loney and others, 1975, and Brew and Ford, 1985). Although stratigraphic relations and fossils indicate that most strata in unit are Silurian in age, deposition of strata in some areas possibly continued into Early Devonian time volcanic breccia, agglomerate, and flows and greenschist and greenstone derived from these rocks. Found with Silurian sedimentary (Ss) and carbonate rocks $(\mathrm{Sc})$ belonging to the Bay of Pillars Formation on southern Kuiu Island (Brew and others, 1984)

SOs Sedimentary rocks (Silurian and Ordovician)Mudstone and graywacke turbidites, subordinate conglomerate, sandstone, and shale, and minor limestone, chert, and basalt flows and breccia. Unit consists of (1) unnamed strata of probable Early Silurian to Middle Ordovician age on Sukkwan and Dall Islands (Eberlein and others, 1983; Gehrels and Saleeby, 1987b; G.E. Gehrels, unpub. data, 1984); (2) unnamed strata of Silurian and (or) Ordovician age on Forrester Island (Clark and others, 1971); (3) Lower Silurian to Lower Ordovician strata belonging to the Descon Formation and unnamed units on southern Prince of Wales Island (Eberlein and others, 1983; Gehrels and Saleeby, 1987a, b; Herreid and others, 1978); (4) part of the Lower Silurian to Lower Ordovician Descon Formation on central and northern Prince of Wales Island (Eberiein and others, 1983; Brew and others, 1984); and (5) thin-bedded black argillite, black chert, and black impure limestone of Ordovician age (Hood Bay Formation) on southern Admiralty Island (Lathram and others, 1965; Carter, 1977)

SOv Volcanic rocks (Silurian and Ordovician)Basaltic pillow flows, pillow breccia, and aquagene tuff; massive andesitic pyroclastic breccia; felsic breccia and tuff; subordinate interbeds of mudstone and graywacke turbidites; and metamorphic equivalents of these strata. Unit consists of (1) mafic to felsic rocks (part of the Descon Formation) on southern Prince of Wales Island (Gehrels and Saleeby, 1986, 1987a); (2) unnamed basalt and metabasalt on Long and southern Dall Islands (Gehrels and Saleeby, 1987b; G.E. Gehrels, unpub. data, 1984); and (3) basaltic rocks (part of the Descon Formation) and unnamed andesitic breccia on central Prince of Wales Island (Eberlein and others, 1983). Age constrained by stratigraphic relations with Lower Silurian to Lower Ordovician sedimentary rocks (unit SOs), intrusive relations with plutons of Early Silurian and Late Ordovician age (unit SOq), and Early Silurian and Late Ordovician potassium-argon apparent ages of volcanic rocks (Eberiein and others, 1983; Gehrels and Saleeby, 1987a)

SOsv Sedimentary and volcanic rocks, undivided (Silurian and Ordovician)-Mudstone and graywacke turbidites, basaltic and andesitic volcanic rocks, and metamorphic equivalents 
of these strata. Unit consists of (1) part of the Descon Formation on Prince of Wales Island (Eberlein and others, 1983); metasedimentary and metavolcanic rocks on southeastern Prince of Wales Island that are assigned to the Descon Formation (Eberlein and others, 1983) but may be part of the Wales Group (called the Wales metamorphic suite by Gehrels and Saleeby, 1987a) (units pOmsv and pOmc) (Redman, 1981); (3) moderately deformed and metamorphosed andesitic to dacitic volcanic rocks and subordinate clastic strata (part of the Descon Formation) on Annette and Duke Islands (Gehrels and others, 1987); (4) unnamed metasedimentary and metavolcanic rocks near Cape Fox (Berg and others, 1978, 1988; G.E. Gehrels and J.B. Saleeby, unpub. data, 1983); and (5) conglomerate, agglomerate, and volcanic breccia (part of the Bay of Pillars Formation) of probable Early Silurian age on northern Prince of Wales Island (Brew and others, 1984)

SOsve

Clastic sedimentary, volcanic, and carbonate rocks, undivided (Silurian and Ordovician)_Interbedded graywacke, mudstone, mafic to felsic volcanic rocks, and limestone that have been regionally metamorphosed as high as greenschist facies (Gehrels and Saleeby, 1987b; G.E. Gehrels, unpub. data, 1984). Found along west coast of Dall Island and on Long Island and interpreted to be coeval with nearby Lower Silurian to Lower Ordovician rocks of the Descon Formation (units SOv, SOs, and SOsv) on the basis of similarities in stratigraphic position and lithic type (Gehrels and Saleeby, 1987b; G.E. Gehrels, unpub. data, 1984)

\section{UNDIVIDED STRATIFIED AND (OR) METAMORPHOSED AND (OR) DEFORMED ROCKS}

KPs Sedimentary rocks (Cretaceous to Permian)Carbonaceous shale, mudstone, and graywacke; subordinate limestone, chert, conglomerate, and mafic volcanic rocks; minor felsic volcanic rocks; and the metamorphosed and deformed equivalents of these rocks. Regional metamorphic grade in these strata and in associated Cretaceous to Permian volcanic and sedimentary rocks (units KPv and KPsv) generally increases from subgreenschist or greenschist facies on southwest to amphibolite facies toward northeast. There are also significant changes in metamorphic grade along northwest trend of these map units. Common rock types in higher grade strata include phyllite, schist, and gneiss. Late Triassic fossils were recovered from carbonaceous slate and limestone assigned to this map unit near Juneau (Ford and Brew, 1977; H.C. Berg, unpub. data, 1981), and similar strata (locally mapped as Triassic clastic sedimentary and carbonate rocks ( $\mathrm{ksc}$ )) on Revillagigedo Island yielded latest Middle Triassic fauna (Silberling and others, 1982). On Revillagigedo Island, phyllite and metagraywacke are locally in depositional contact with crinoidal marble of known Permian age (unit $\mathrm{Pc}$ ) and are interbedded with crinoidal marble of probable Permian age (Berg and others, 1978, 1988; H.C. Berg, unpub. data, 1975). Some strata included in this unit are interpreted to be Cretaceous or Jurassic in age on the basis of the following observations: (1) Berg and others $(1978,1988)$ report that metasedimentary rocks in this unit on Revillagigedo Island are locally identical in protolith to Cretaceous and Jurassic strata (unit KJs) on Annette and Gravina Islands; (2) Brew and others (1984) suggest that some rocks in this unit on mainland east of Kupreanof Island may have Cretaceous or Jurassic protolith ages; and (3) Buddington and Chapin (1929, p. 74) report that conglomerate and phyllite in this unit on mainland east of Admiralty Island are lithically similar to conglomerate and slate of Cretaceous and Jurassic age (unit KJs) on eastern Admiralty Island. Contact between rocks of Cretaceous and Jurassic age (units KJs, KJv, and KJsv) and Cretaceous to Permian rocks in this and associated map units (units KPv and KPsv) is located along northeast margin of relatively homogeneous metagraywacke and phyllite.

Intrusive bodies of Late Cretaceous age (unit Kgt) place a younger limit on depositional age of these strata. Age of metamorphism and deformation has traditionally been interpreted to be Late Cretaceous and (or) early Tertiary (Buddington and Chapin, 1929). However, recognition of (1) an unconformity separating metasedimentary and metavolcanic rocks of probable Triassic or Permian age (unit KPsv) from less metamorphosed Cretaceous and Jurassic strata (unit KJs) northwest of Juneau (Redman, 1984a); and (2) a greater degree of metamorphism and deformation in this unit than in strata of probable Cretaceous and Jurassic age on Revillagigedo Island (G.E. Gehrels, unpub. data, 1984) suggest that some rocks in this unit may have been metamorphosed and deformed prior to deposition of Cretaceous and Jurassic strata. 
Consists of unnamed rocks on Revillagigedo Island (Berg and others, 1978, 1988) and on mainland east of Kupreanof Island (Brew and others, 1984), east of Admiralty Island (Brew and Grybeck, 1984; Buddington and Chapin, 1929), and east of Juneau (Ford and Brew, 1973, 1977; Brew and Ford, 1977, 1985)

KPv Volcanic rocks (Cretaceous to Permian)Andesitic or basaltic flows and locally fragmental rocks, subordinate clastic strata and carbonate, and the metamorphosed and deformed equivalents of these rocks. Regional metamorphism of these strata is similar to that described above for Cretaceous to Permian sedimentary rocks (KPs). Common rock types in higher grade regions include schist, gneiss, and amphibolite, although some of this amphibolite may be metagabbro (see sedimentary and volcanic rock unit KPsv described below). Graphitic slate assigned to unit contains Late Triassic fossils near Juneau (Brew and Grybeck, 1984, p. 31), and marble intercalated with metavolcanic rocks contains Permian and Permian(?) fossils near Juneau, along coast southeast of Juneau, and in Endicott Arm (Buddington and Chapin, 1929, p. 73, 119; Ford and Brew, 1973; Brew and Grybeck, 1984, p. 30-31). Minimum depositional age constrained by interbedded Cretaceous to Permian sedimentary rocks (KPs) and by crosscutting Late Cretaceous intrusive bodies (unit $\mathrm{Kgt}$ ). Consists of unnamed rocks on Revillagigedo Island (Berg and others, 1978, 1988) and on mainland east of Kupreanof Island (Brew and others, 1984), east of Admiralty Island (Brew and Grybeck, 1984; Buddington and Chapin, 1929), and east of Juneau (Ford and Brew, 1973, 1977; Brew and Ford, 1977, 1985)

KPsv Sedimentary and volcanic rocks, undivided (Cretaceous to Permian)-Shale, mudstone, graywacke, andesitic or basaltic rocks, subordinate chert and carbonate rocks, and the regionally metamorphosed equivalents of these strata. Nature and age of metamorphism is similar to that described above for Cretaceous to Permian sedimentary rocks (KPs). Protolith age indicated by stratigraphic relations with sedimentary and volcanic rocks of Cretaceous to Permian age (units KPs and $\mathrm{KPv}$ ). Stippled area in unit southeast of Revillagigedo Island represents metasedimentary and metavolcanic rocks intruded by deformed and metamorphosed gabbro (recrystallized to amphibolite) that is apparently related to foliated Paleocene and Cretaceous tonalite (TKt) (G.E. Gehrels and
J.B. Saleeby, unpub. data, 1984). The Work Channel amphibolite to southeast in British Columbia (Hutchison, 1982) and some amphibolite in Cretaceous to Permian map units to northwest may consist in part of correlative metagabbro. Unit found on (1) Revillagigedo Island and adjacent areas of mainland to southeast (Berg and others, 1978, 1988) and northwest (Elliott and Koch, 1981); (2) mainland east of Admiralty Island (Buddington and Chapin, 1929; Brew and Grybeck, 1984; Brew and Ford 1977, 1985; Ford and Brew, 1973, 1977); and (3) east side of Lynn Canal (Buddington and Chapin, 1929; Redman, 1984a)

KPsvc Clastic sedimentary, volcanic, and carbonate rocks (Cretaceous to Permian)_Unnamed fossiliferous argillite of Cretaceous age; variably metamorphosed chert, tuffaceous sandstone, felsic tuff, argillite, and light-gray, thin-bedded limestone of Mesozoic or Paleozoic age; highly sheared metasedimentary, metavolcanic, and granodioritic rocks of Mesozoic and Paleozoic(?) age; and amphibolite, gneiss, schist, and marble of Mesozoic or Paleozoic age (Johnson and Karl, 1985; Loney and others, 1975). We assign a maximum age of Permian on the basis of our interpretation that the oldest rocks in this unit are found beneath nearby Triassic basaltic rocks ( $\mathrm{kb}$ ) and may be equivalent to Permian strata that underlie correlative Triassic basaltic rocks in Wrangell Mountains of southern Alaska (Plafker and others, 1976; Jones and others, 1977). Found on Chichagof, Baranof, and Yakobi Islands. Strata in this unit are probably not correlative with rocks belonging to other Cretaceous to Permian units (units KPs, KPv, and KPsv). Areas that may be underlain by a significant proportion of intrusive rock are shown with a stipple pattern

JMsv

Sedimentary and volcanic rocks, undivided (Jurassic to Mississippian)—Diverse assemblage of sedimentary and volcanic rocks and their metamorphic equivalents. Found near British Columbia-Alaska border northeast of Revillagigedo Island (Berg and others, 1978, 1988; Elliott and Koch, 1981) and east of Juneau (Souther and others, 1979; Souther, 1971). Unit consists of (1) unnamed Middle Jurassic rhyolite and andesite; (2) Lower Jurassic andesite, basalt, conglomerate, and sandstone of the Hazelton Group; (3) Upper Triassic andesite and clastic sedimentary rocks; (4) Permian limestone; and (5) Carboniferous greenstone, limestone, and clastic sedimentary rocks (Hutchison and others, 1979; Berg and others, 1978, 1988; Souther and others, 1979; Souther, 1971). 
Rocks locally metamorphosed to semischist, phyllite, and schist. Nearby metasedimentary and metavolcanic rocks of pre-Tertiary age (pTmsv) probably consist in large part of higher grade equivalents of these strata

$\mathrm{kPC} \quad$ Carbonate rocks (Triassic and (or) Permian)Unfossiliferous marble on mainland northwest of Revillagigedo Island (H.C. Berg, unpub. data, 1975) and on and northeast of Etolin Island (Brew and others, 1984). Age inferred from similarity with Triassic and Permian marble layers included in units of Cretaceous to Permian sedimentary rocks (KPs) and of Permian carbonate rocks $(\mathrm{Pc})$

KPsv Sedimentary and volcanic rocks, undivided (Triassic and Permian)-Andesitic to basaltic pillow flows, breccia, and tuff; felsic tuff; graywacke, mudstone, shale, chert, conglomerate, and carbonate; and the metamorphic equivalents of these strata. Unit consists of the Barlow Cove Formation (Barker, 1957) and strata belonging to the Hyd Formation (Upper Triassic) and the Cannery Formation (Lower Permian) (Lathram and others, 1965). Phyllite, greenstone, greenschist, and marble are common rock types in this unit, but nature and age of metamorphism are poorly known

KOsv Sedimentary and volcanic rocks, undivided (Triassic to Ordovician)-Clastic sedimentary rocks, subordinate mafic to felsic volcanic rocks, thin- to thick-bedded gray carbonate, chert, and minor ultramafic rocks that have been regionally metamorphosed to slate, phyllite, greenschist, schist, gneiss, and marble in many areas. Age and grades of metamorphism have not been reliably determined. Rocks assigned to unit on Admiralty Island belong to the Gambier Bay Formation, the Retreat Group, and the "undifferentiated metamorphic rocks" and the "migmatite, gneiss, and feldspathic schist" units of Lathram and others (1965). Devonian fossils were recovered from marble in the Gambier Bay Formation; the Retreat Group is inferred to be Devonian in age on the basis of correlation with the Gambier Bay Formation; and the undivided metamorphic rocks are undated (Lathram and others, 1965). The Triassic to Ordovician age assignment on Admiralty Island reflects our interpretation that this map unit consists primarily of regionally metamorphosed and deformed strata correlative with the Upper Triassic Hyd Formation (unit Ksv), the Permian Pybus Formation (unit $\mathrm{Pc}$ ) and Cannery Formation (unit Ps on Admiralty Island), the Mississippian and Devonian Cannery Formation (unit MDsv on Kupreanof Island), the Ordovician Hood Bay Formation (unit SOs), and various strata elsewhere assigned to Devonian, Silurian, or Ordovician units. Rocks in part of unit may also belong to belt of regionally disrupted rocks (units KDsd and KDvd). Areas on Admiralty Island that may be underlain by a significant proportion of younger intrusive rock are shown with a stipple pattern.

In the Chilkat Range west of Haines unit consists of unnamed metasedimentary and metavolcanic rocks (Mackevett and others, 1974; E.C. Robertson, written commun., 1984; Redman, 1984b) that are of known Mississippian age (Redman and others, 1985) and probable Triassic to middle Paleozoic age (MacKevett and others, 1974; Berg and Grybeck, 1980; Redman, 1984b). These rocks are herein interpreted to be predominantly correlative with sedimentary and volcanic rocks of Permian, Devonian, and Silurian age in Glacier Bay (Brew and others, 1978) and in the Chilkat Range (Lathram and others, 1959; Brew and Ford, 1985) and of Triassic to Ordovician age along British Columbia-Alaska border north of Glacier Bay (Campbell and Dodds, 1983)

KOc Carbonate rocks (Triassic to Ordovician)Carbonate rocks regionally metamorphosed to gray marble (MacKevett and others, 1974; Lathram and others, 1959; Brew and Ford, 1985; Redman and others, 1985). Fossils of Pennsylvanian(?) or Permian(?), Paleozoic(?), and Devonian(?) or Silurian(?) age were recovered from unit west of Haines (Mackevett and others, 1974) and fossils of probable Mississippian age were recovered from marble in associated Triassic to Ordovician strata (unit KOsv) (Redman and others, 1985). Adjacent units in British Columbia consist of carbonate rocks of Triassic, Devonian, Silurian, and Ordovician age (Campbell and Dodds, 1983). Age of strata in unit on Admiralty Island (referred to as part of Gambier Bay Formation) is constrained by stratigraphic relations with Triassic to Ordovician clastic strata (unit KOsv). Regional map patterns suggest that most carbonate rocks in this map unit are probably of Silurian age and correlative with the Kennel Creek, Pyramid Peak, and Willoughby Limestones (unit Sc)

PDsv Sedimentary and volcanic rocks, undivided (Pennsylvanian to Devonian)-Saginaw Bay Formation on Kuiu Island. From youngest to oldest, unit consists of silty limestone, calcareous chert and limestone, black chert, and massive aquagene tuff and pillow breccia (Muffler, 1967). Silty limestone and calcareous chert and limestone are known to be Middle and 
Lower Pennsylvanian; age of black chert is not known directly; and volcanic rocks yielded earliest Late to latest Early Devonian conodonts (Dutro and others, 1981; Brew and others, 1984)

DSv Volcanic rocks (Devonian and Silurian)Unnamed Devonian or Silurian andesitic(?) volcanic rocks found in a fault slice on northern Kuiu Island (Muffler, 1967; Brew and others, 1984); unnamed Devonian and Silurian basaltic and (or) andesitic rocks in Glacier Bay (Brew and others, 1978); and unnamed Devonian(?) and Devonian to Silurian(?) basalt and andesite in the Chilkat Range and along west shore of Lynn Canal (Lathram and others, 1959; Loney and others, 1975; Brew and Ford, 1985). Volcanic rocks in Glacier Bay and in Chilkat Range may be in part or entirely correlative with the Upper Devonian Freshwater Bay Formation (unit Dv) or volcanic rocks of Silurian age (units Sv or SOv), or, as suggested by Brew and Ford (1985), they may range in age from Middle Devonian through Late Silurian

Sedimentary and volcanic rocks, undivided (Devonian to Ordovician)-Graywacke, mudstone, shale, limestone, and subordinate mafic to intermediate volcanic rocks that have been metamorphosed in most areas to hornfels, slate, phyllite, schist, amphibolite, marble, gneiss, and granofels. Unit consists of unnamed rocks on northeastern Chichagof Island, in Glacier Bay area, and in the Chilkat Range. Loney and others (1975) suggest that metamorphic rocks on Chichagof Island were derived mainly from the Point Augusta Formation (unit Ss) and from Devonian volcanic rocks of the Freshwater Bay Formation (unit Dv). In Glacier Bay area and the Chilkat Range rocks are probably the metamorphic equivalents of Devonian and Silurian strata found nearby (units Ds, Dv, Dcg, Ss, Sc, DSsc, DSc, and DSv) (Lathram and others, 1959; Brew and others, 1978; Brew and Ford, 1985). We suggest that this unit also includes rocks of Ordovician age because Ordovician strata are found in contiguous map units northwest of Glacier Bay in British Columbia (Campbell and Dodds, 1983). On northeastern Chichagof Island, strata were metamorphosed to hornblende-hornfels facies during emplacement of adjacent Cretaceous intrusive rocks (Loney and others, 1975). Metamorphism in Glacier Bay area is also interpreted to have occurred during Cretaceous time (Brew and others, 1978)

DOc Carbonate rocks (Devonian to Ordovician)Carbonate rocks that were metamorphosed to thin- to thick-bedded, dark-gray to white marble. Consists of unnamed rocks on northeastern Chichagof Island and in Glacier Bay area. Loney and others (1975) suggest that marble on Chichagof Island was derived primarily from limestone in the Point Augusta Formation (unit Sc). Marble in Glacier Bay area was derived in large part from limestone of Devonian (unit Dc), Silurian (unit Sc), or Devonian and Silurian (DSc) age (Brew and others, 1978). Some marble in unit may be correlative with Ordovician limestone in map units along Alaska-British Columbia border northwest of Glacier Bay (Campbell and Dodds, 1983). Metamorphic relations are the same as for Devonian to Ordovician sedimentary and volcanic rocks (DOsv)

DSc Carbonate rocks (Devonian and Silurian)Thin, discontinuous, unfossiliferous limestone layers associated with Devonian and Silurian volcanic rocks (DSv) in the Chilkat Range (Lathram and others, 1959; Brew and Ford, 1985)

DSsc Sedimentary rocks (Devonian and Silurian)_On north-central Prince of Wales Island unit consists of unnamed limestone, sandstone, calcareous mudstone, and polymictic conglomerate interpreted to be facies equivalents of the Silurian Heceta Limestone (unit Sc), associated Silurian clastic strata (units Ss and Scg), and the Lower Devonian Karheen Formation (unit Dcg) (Eberiein and others, 1983). In Glacier Bay, unit consists of unnamed clastic sedimentary and minor carbonate and volcanic rocks and of Devonian and (or) Silurian argillite and limestone (Rendu Formation) (Rossman, 1963; Brew and others, 1978; Brew and Ford, 1985). Strata in Glacier Bay may be lateral equivalents of the Tidal Formation (Upper Silurian) (units Ss and Sc), the Point Augusta Formation (Upper? Silurian) (unit $\mathrm{Ss}$ and $\mathrm{Sc}$ ) and lower part of the Devonian Cedar Cove Formation (units Dcg and Ds)

\section{HIGHLY METAMORPHOSED AND (OR) DEFORMED ROCKS Melange}

Melange (Cretaceous)-Melange of regionally disrupted, deformed, and metamorphosed marine sedimentary and volcanic rocks. Divided into:

Ksvm Sedimentary and volcanic rocks, undivided-Consists of (1) blocks as much as several kilometers in length of marine sedimentary and volcanic rocks, and their metamorphic equivalents, that are bounded by faults or shear zones; and (2) blocks as much as several tens of meters in length of 
marine sedimentary and volcanic rocks, and their metamorphic equivalents, enclosed in a matrix of moderately metamorphosed and penetratively sheared graywacke, argillite, tuff, and pillow breccia. Common lithic types in blocks include tuffaceous argillite, tuff, greenstone, graywacke, chert, limestone, marble, phyllite, schist, and minor granitic rocks. Fossils from blocks are Early Cretaceous, Late Jurassic, and Jurassic(?) or Triassic(?) in age (Loney and others, 1975; Johnson and Karl, 1985). Minimum age of unit is constrained by (1) mid-Cretaceous potassium-argon apparent ages on metamorphic minerals in the melange on Chichagof Island (Decker and others, 1980); (2) Early Cretaceous fossils in sedimentary matrix material near Sitka on Baranof Island (Plafker and others, 1976); and (3) Early Cretaceous fossils in matrix material near the coast northwest of Cross Sound (Plafker and others, 1977; George Plafker, written commun., 1984). Cretaceous age assigned to unit refers to time during which melange is interpreted to have formed. Metamorphic grade is primarily subgreenschist, greenschist, and, south of Cross Sound, glaucophane-schist facies (Decker and others, 1980). On Chichagof Island, unit consists of the Khaz Formation, which is a melange of blocks enclosed in a sedimentary and volcanic matrix, and the Freeburn assemblage, which consists of fault-bounded blocks of sedimentary and volcanic rocks (Decker, 1980; Karl and others, 1982; Johnson and Karl, 1985). The Freeburn assemblage comprises rocks described by Loney and others (1975) as the Pinnacle Peak Phyllite and an unnamed schist unit in the Kelp Bay Group. On Baranof Island, unit consists of rocks described by Loney and others (1975) as the Khaz Formation, part of the undivided Kelp Bay Group, and an unnamed "schist, gneiss, amphibolite, and greenschist" unit (Karl and others, 1982). Northwest of Cross Sound, unit consists of melange between Brady Glacier and Border Ranges faults (Tarr Inlet suture zone) that is continuous and probably correlative with part of melange on Chichagof and Baranof Islands (Decker and Plafker, 1982) and part of melange facies of the Yakutat Group west of the Fairweather fault (Plafker and others, 1977; George Plafker, written commun., 1984)

Sedimentary rocks-Includes sedimentary and metasedimentary rocks that are similar in structural and metamorphic characteristics to rocks in the Cretaceous sedimentary and volcanic melange unit (Ksvm). Common lithic types include dark-gray phyllite, light- gray quartzite, and graywacke semischist. Age of formation of this melange unit is constrained by stratigraphic and structural similarities with rocks in associated Cretaceous melange units (units Ksvm and $\mathrm{Kvm}$ ). Fossils were not recovered from rocks in this unit. Consists of unnamed rocks mapped by Loney and others (1975) as "phyllite" and "graywacke semischist" units on Baranof Island

Kvm Volcanic rocks-Includes mafic volcanic and metavoicanic rocks that resemble rocks in the Cretaceous sedimentary and volcanic rocks melange unit (Ksvm) in structural and metamorphic characteristics. Common lithic types include greenstone, greenschist, and minor phyllite, graywacke semischist, marble, and metachert. Age of formation of this melange unit is constrained by stratigraphic and structural similarities with rocks in associated Cretaceous melange units (units $\mathrm{Ksvm}$ and $\mathrm{Ksm}$ ). Consists of the Waterfall Greenstone on western Chichagof Island, which yielded radiolaria of Early Cretaceous age (Johnson and Karl, 1985), and unnamed metavolcanic rocks on Baranof Island that are referred to as "greenschist and greenstone" unit by Loney and others (1975)

\section{Disrupted rocks}

Disrupted rocks (Cretaceous to Devonian)Belt of regionally disrupted rocks that have some characteristics of a melange, but relations between blocks and matrix are uncertain. Divided into:

KDsd Sedimentary rocks-Deformed, disrupted, and metamorphosed graywacke, siltstone, mudstone, and subordinate chert, limestone, and volcanic and intrusive rocks that belong to a belt of regionally disrupted rocks in the Kupreanof-Etolin Islands area. Common metamorphic rock types include subgreenschist- to greenschist-facies graywacke semischist, phyllite, argillite, slate, and subordinate greenstone, greenschist, and marble. Unit consists of blocks as much as several kilometers in length of Triassic sedimentary and volcanic rocks (ksv), Permian carbonate rocks ( $\mathrm{Pc}$ ), and Devonian carbonate rocks $(\mathrm{Dc})$ enclosed in a matrix of strata belonging to the Stephens Passage Group (Lower Cretaceous and Jurassic, unit KJs) and perhaps the Cannery Formation (Mississippian and Upper Devonian, unit MDsv) or other Mesozoic or Paleozoic units (Brew, 1982; Brew and others, 1984; H.C. Berg, unpub. data, 1978; McClelland and Gehrels, 1987)

KDvd Volcanic rocks-Deformed, disrupted, and metamorphosed mafic to intermediate and 
minor felsic volcanic rocks that belong to a belt of regionally disrupted rocks in the Kupreanof-Zarembo Islands area. Rocks generally metamorphosed to greenschist and greenstone. Presence of relict pyroxene phenocrysts suggests that some metavolcanic rocks were probably derived from Cretaceous and Jurassic volcanic rocks (KJv), although metavolcanic rocks of Triassic (unit Kv) and Mississippian and Late Devonian (unit MDsv) age may also be included (Brew and others, 1984; McClelland and Gehrels, 1987)

Metamorphic rocks

Metamorphic rocks (pre-Tertiary and preOrdovician)-Units in which primary stratigraphic relations were obliterated during regional metamorphism. Divided into:

pTmsv Metasedimentary and metavolcanic rocks (pre-Tertiary)-Metasedimentary and metavolcanic rocks derived from pre-Tertiary sedimentary and volcanic rocks during regional amphibolite- and local granulitefacies metamorphism. Common rock types include pelitic, semipelitic, and quartzofeldspathic schist and gneiss, and subordinate amphibolite, quartzite, marble, and calc-silicate. Protoliths are interpreted to be argillaceous marine strata, limestone, chert, subordinate mafic to felsic volcanic rocks, and minor intrusive rocks. Areas in which there may be a significant proportion of unmapped Tertiary or Cretaceous intrusive rocks are shown with a stipple pattern. Such areas comprise migmatite map units in some reports cited in this study (for example, Brew and Grybeck, 1984; Brew and others, 1984; Brew and Ford, 1985).

Minimum age of rocks in unit is constrained by crosscutting tonalitic bodies of Paleocene and Late Cretaceous age (unit TKt) in the Coast Mountains (Gehrels and others, 1984). Protolith ages of Cretaceous(?), Jurassic(?), Triassic, Permian(?), Carboniferous(?), and Proterozoic(?) are indicated by (1) relations along Alaska-British Columbia border east of Juneau which suggest that rocks in this unit grade into strata of Triassic and older age and that these Triassic rocks locally contain clasts of older metamorphic rocks (Souther, 1971); (2) a preliminary rubidium-strontium isochron of Proterozoic apparent age (R.L. Armstrong, oral commun., 1984) determined on high-grade metamorphic rocks along Alaska-British Columbia border north of Juneau (Souther and others, 1979; Werner, 1978); (3) occurrence of Triassic strata near Alaska-British Columbia border north of Juneau (not shown on map) which are adjacent to, and perhaps overlie, high-grade metamorphic rocks (Brew and others, 1985); (4) relations southeast of map area in Portland Canal-Terrace area which suggest that similar metamorphic rocks were derived from Cretaceous and Jurassic strata (Douglas, 1986), the Jurassic Bowser Lake Group (Woodsworth and others, 1983, p. 13; Hill, 1985a), and strata of probable Permian (Hill, 1985b) and pre-Permian age (Hutchison, 1982); and (5) map patterns suggesting that rocks in unit were derived in part from nearby Jurassic to Mississippian sedimentary and volcanic rocks (JMsv). Regional metamorphism apparently occurred (1) during early Tertiary to Late Cretaceous time (Forbes and Engels, 1970; Smith and Diggles, 1981; Gehrels and others, 1984); (2) after deposition of sedimentary and volcanic rocks of probable Triassic or Permian age (belonging to map unit KPsv) and prior to deposition of Cretaceous and Jurassic strata (unit KJs) (see discussion of Cretaceous to Permian sedimentary rocks, KPs); (3) in part prior to Late Triassic time (Souther, 1971; Brew and others, 1985); and (4) perhaps during mid-Paleozoic to Proterozoic or other time. Unit consists of unnamed rocks in Coast Mountains east of Ketchikan (Berg and others, 1978, 1988; Elliott and Koch, 1981), east of Petersburg (Brew and others, 1984; Souther and others, 1979), near Tracy Arm (Brew and Grybeck, 1984), near Juneau (Ford and Brew, 1973; Brew and Ford, 1977, 1985; Souther and others, 1979), southeast of Haines (Souther and others, 1979; Werner, 1978), and near Skagway (Redman and others, 1984)

pTmc Metacarbonate rocks (pre-Tertiary)Metacarbonate rocks derived from preTertiary carbonate rocks and carbonate-rich clastic strata during regional amphibolite-and local granulite-facies metamorphism. Found as discontinuous marble lenses, as thick continuous marble layers, and as calc-silicate gneiss. Age constrained by intercalation with pre-Tertiary metasedimentary and metavolcanic rocks (pTmsv) described above. Found in Coast Mountains northeast of Petersburg (Brew and others, 1984) and southeast of Juneau (Brew and Grybeck, 1984)

pOmsv Metasedimentary and metavolcanic rocks (pre-Ordovician)_Metasedimentary and metavolcanic rocks derived from preOrdovician basaltic to andesitic pillow flows, pillow breccia, and tuff breccia, volcaniclastic graywacke and mudstone, and minor limestone and felsic volcanic breccia and tuff during regional greenschist- and local amphibolite-facies metamorphism. Common 
rock types include greenschist, greenstone, quartz-white mica schist, and marble. Radiometric age constraints suggest that metamorphism occurred during Early Ordovician to Middle Cambrian time (Turner and others, 1977; Gehrels and Saleeby, 1987a, b; M.A. Lanphere, oral commun., 1984). Pre-Ordovician protolith ages are indicated by intrusive relations with Cambrian diorite and granodiorite $(€ \mathrm{dg})$ on eastern Prince of Wales Island and on southernmost Gravina Island (Gehrels and others, 1987). Unit consists of part of the Wales Group (called the Wales metamorphic suite by Gehrels and Saleeby, 1987a) on (1) south-central Prince of Wales Island (Eberlein and others, 1983; Gehrels and Saleeby, 1987a); (2) small islands south of Gravina Island (Gehrels and others, 1987); and (3) Dall Island (Gehrels and Saleeby, 1987b; G.E. Gehrels, unpub. data, 1984)

pOmc

Metacarbonate rocks (pre-Ordovician)Metacarbonate rocks derived from preOrdovician carbonate rocks during regional greenschist- and local amphibolite-facies metamorphism. Found as thin to thick marble layers and lenses intercalated with pre-Ordovician metasedimentary and metavolcanic rocks (pOmsv). Pre-Ordovician protolith age and Early Ordovician to Middle Cambrian metamorphic age are indicated by intercalation with the pre-Ordovician metasedimentary and metavolcanic rocks (pOmsv). Unit consists of part of the Wales Group (called the Wales metamorphic suite by Gehrels and Saleeby, 1987a) on southern Prince of Wales Island (Eberlein and others, 1983)

\section{INTRUSIVE ROCKS}

[May include metamorphosed and (or) deformed rocks]

Tgb Gabbro (Miocene and Oligocene)-Layered and locally zoned bodies of two-pyroxene \pm olivine \pm biotite \pm hornblende \pm quartz gabbro and subordinate troctolite, peridotite, leucogabbro, diorite, and tonalite. Unit consists of stocks on Revillagigedo Island and adjacent mainland (Berg and others, 1978, 1988; Koch and Elliott, 1984), northern Kupreanof and Kuiu Islands (Brew and others, 1984), Chichagof Island (Johnson and Karl, 1985; Loney and others, 1975), and north of Cross Sound (Brew and others, 1978). Stocks on Revilagigedo Island and adjacent areas of mainland yield potassiumargon apparent ages of early Miocene and late Oligocene (Smith and Diggles, 1981), and large body (La Perouse gabbro) northwest of Cross Sound yields a ${ }^{40} \mathrm{Ar} /{ }^{39} \mathrm{Ar}$ apparent age of Oligocene (Loney and
Himmelberg, 1983)

Tgr Granite (Miocene and Oligocene)-Biotite \pm hornblende \pm pyroxene granite, alkali granite, quartz monzonite, and subordinate syenite, granodiorite, and diorite. Unit consists of (1) stocks on mainland southeast of Revillagigedo Island that yield potassiumargon apparent ages of early Miocene and Oligocene (Berg and others, 1978; 1988); (2) large plutons of Miocene and (or) Oligocene age on Etolin, Zarembo, Kupreanof, and Kuiu Islands (Brew and others, 1984); and (3) part of the Oligocene Tkope River intrusions along Alaska-British Columbia border north of Glacier Bay (Mackevett and others, 1974; Campbell and Dodds, 1983)

Tgd Granodiorite (Oligocene and Eocene)-Biotite \pm hornblende \pm muscovite \pm garnet granodiorite, granite, quartz monzonite, tonalite, and quartz diorite. Unit consists of muscovite- and locally garnet-bearing granodiorite, granite, and tonalite on Baranof and Chichagof Islands and in Glacier Bay. Where dated, these intrusive bodies yield Eocene potassium-argon apparent ages (Loney and others, 1975; Decker and Plafker, 1982; Johnson and Karl, 1985; Brew and others, 1978). In the Chilkat Range and on southeastern Baranof Island, intrusive bodies consist of biotite- and hornblende-bearing quartz diorite and granodiorite that yield Oligocene potassiumargon apparent ages (Loney and others, 1975; MacKevett and others, 1974; Brew and Ford, 1985)

Tg Granodiorite (Eocene)-Biotite-dominant, hornblende- and sphene-bearing granodiorite and subordinate quartz monzonite, quartz diorite, and leucogranite found in Coast Mountains (Berg and others, 1978, 1988; Elliott and Koch, 1981; Brew and others, 1984; Webster, 1984; Brew and Grybeck, 1984; Brew and Ford, 1977, 1985; Souther and others, 1979; Redman and others, 1984; Barker and others, 1986). Concordant potassium-argon apparent ages on hornblende and biotite (Forbes and Engels, 1970; Smith and others, 1979) and uranium-lead (zircon) apparent ages (Gehrels and others, 1984) indicate emplacement during Eocene time

Tgt Granodiorite and tonalite (Paleocene)-Biotitedominant, hornblende-bearing granodiorite and tonalite containing local foliation and layering. Uraninum-lead (zircon) data indicate emplacement during Paleocene time (Gehrels and others, 1984). Found in Coast Mountains east of Petersburg (Brew and others, 1984), east of Juneau (Brew and Ford, 1977, 1985; Gehrels and others, 
1984), and near Skagway (Barker and others, 1986)

TKt Tonalite (Paleocene and Cretaceous)Hornblende-dominant, biotite-bearing tonalite and subordinate quartz diorite found as steeply dipping, foliated, and locally lineated sills in Coast Mountains (Brew and Ford, 1981). Found near Ketchikan (Berg and others, 1978, 1988;' Elliott and Koch, 1981), near Petersburg (Brew and others, 1984), near Juneau (Brew and Grybeck, 1984; Brew and Ford, 1977, 1985), and north of Haines (MacKevett and others, 1974; Redman and others, 1984; E.C. Robertson, written commun., 1984; Barker and others, 1986). Field and uranium-lead (zircon) data indicate emplacement in Paleocene and Late Cretaceous time, during waning stages of deformation and metamorphism in Coast Mountains (Gehrels and others, 1984; Brew and Ford, 1981)

TKg Granodiorite (Paleocene and Cretaceous)Diverse assemblage of generally foliated and layered granodiorite, quartz monzonite, tonalite, and their metamorphic equivalents. May include a significant component of preTertiary metasedimentary and metavolcanic rocks (pTmsv) in some areas. Where recognized, such areas are indicated by a stipple pattern. Constraints on age provided by crosscutting Eocene granodiorite plutons ( $\mathrm{Tg}$ ) and the interpretation that some rocks in this unit have experienced regional early Tertiary to Late Cretaceous metamorphism (Forbes and Engels, 1970; Smith and Diggles, 1981). We suspect, however, that most rocks in this unit are correlative with rocks in the Paleocene granodiorite and tonalite unit (unit Tgt). Found in Coast Mountains east and north of Ketchikan (Berg and others, 1978, 1988; Elliott and Koch, 1981), east of Petersburg (Brew and others, 1984), east of Admiralty Island (Brew and Grybeck, 1984), and in Skagway area (Barker and others, 1986)

Kgt Granodiorite and Tonalite (Cretaceous)—Small plutons to batholiths of granodiorite, tonalite, and subordinate quartz monzonite to quartz diorite and diorite. Most bodies contain biotite and hornblende, many have magmatic epidote and garnet and are plagioclase porphyritic, and some contain pyroxene and (or) muscovite. Potassiumargon and ${ }^{40} \mathrm{Ar} /{ }^{39} \mathrm{Ar}$, and uranium-lead apparent ages of these bodies are generally Late Cretaceous (Smith and Diggles, 1981; Brew and others, 1984; Sutter and Crawford, 1985; Rubin and Saleeby, 1987). Unit consists of plutons on Revillagigedo Island and adjacent mainland (Berg and others, 1978, 1988; Eberlein and others,
1983; Zen and Hammarstrom, 1984a,b), in Etolin-Kupreanof Islands area (Brew and others, 1984; Burrell, 1984; Buddington and Chapin, 1929), on mainland east of Admiralty Island (Buddington and Chapin, 1929; Brew and Grybeck, 1984; Souther and others, 1979; Brew and Ford, 1985), and in the Haines region (Mackevett and others, 1974; Redman and others, 1984; Earl Redman, written commun., 1985). Plutons that are mineralogically or compositionally different from main suite of intrusive bodies are queried on geologic map

$\mathrm{Kdb}$ Diorite and gabbro (Cretaceous)-Hornblende diorite and gabbro that grades laterally into granodiorite and quartz diorite (unit $\mathrm{Kgt}$ ). Potassium-argon ages are Late Cretaceous (Redman and others, 1984). Found in the Haines area

Kum Ultramafic rocks (Cretaceous)_-Ultramafic intrusive bodies of magnetite-bearing hornblende clinopyroxenite and subordinate dunite, peridotite, and hornblendite (Taylor, 1967). Several complexes are concentrically zoned from a core of dunite to rocks containing progressively less olivine and more hornblende and magnetite. Zoned bodies commonly intrude a two-pyroxene gabbro known to be of Late Triassic age on Duke Island (Gehrels and others, 1987). Geologic and geochemical considerations suggest that rocks in these bodies may be genetically related to some Cretaceous and Jurassic volcanic rocks (KJv) (Berg and others, 1972; Irvine, 1973). Potassium-argon apparent ages of the ultramafic rocks indicate emplacement during Early Cretaceous time (Lanphere and Eberlein, 1966). Rocks belonging to this suite are found on (1) Duke Island (Irvine, 1967, 1974); (2) Annette and Revillagigedo Islands (Berg and others, 1978, 1988); (3) small islands west of Etolin Island (Himmelberg and others, 1986) and Kupreanof Island (Brew and others, 1984); and (4) on mainland near Myers Chuck (Ruckmick and Noble, 1959), Tracy Arm (Brew and Grybeck, 1984), and Klukwan (MacKevett and others, 1974).

Undated ultramafic rocks provisionally assigned to unit on the basis of similar lithic type are queried on geologic map and consist of (1) hormblendite and hornblende pyroxenite on Revillagigedo Island (Berg and others, 1978, 1988); (2) peridotite, dunite, and pyroxenite in Coast Mountains near Tracy Arm (Brew and Grybeck, 1984; Grybeck and others, 1977); (3) hornblendite and pyroxene- and hornblende-bearing gabbro on eastern Admiralty Island (Lathram and others, 1965); (4) serpentinized peridotite or pyroxenite on north-central 
Admiralty Island (Lathram and others, 1965); and (5) peridotite and serpentinite on eastern Baranof Island (Loney and others, 1975)

Granodiorite (Cretaceous)_A heterogeneous suite of plutons consisting primarily of biotite, hornblende, magnetite \pm pyroxene \pm garnet granodiorite and subordinate quartz monzonite, tonalite, trondhjemite, and quartz diorite. On Chichagof Island these plutons are associated with Early Cretaceous gabbro (unit $\mathrm{Kgb}$ ) and diorite (unit $\mathrm{Kd}$ ). Many intrusive bodies show crude zoning from leucocratic rocks in interior to progressively more mafic rocks toward margins. Potassium-argon apparent ages record emplacement primarily during Early Cretaceous time, although similar intrusive bodies northwest of Glacier Bay in Canada also yield Late Jurassic potassium-argon apparent ages (Chris Dodds, oral commun., 1984). Some bodies could also be of Silurian or Ordovician age. Found on Dall Island (Gehrels and Saleeby, 1987b; G.E. Gehrels, unpub. data, 1984), Prince of Wales Island and adjacent smaller islands (Eberlein and others, 1983; Brew and others, 1984), Kuiu Island (Brew and others, 1984), Admiralty Island (Lathram and others, 1965), Chichagof Island (Loney and others, 1975; Johnson and Karl, 1985), north of Cross Sound (Decker and Plafker, 1982; George Plafker, written commun., 1984), in Glacier Bay area (Brew and others, 1978), and in Chilkat Range (Lathram and others, 1959; Sonnevil, 1981; Brew and Ford, 1985; MacKevett and others, 1974; E.C. Robertson, written commun., 1984)

Diorite (Cretaceous)-Primarily hornblende \pm biotite \pm clinopyroxene diorite and subordinate quartz diorite and gabbro. Generally found in association with Early Cretaceous granodiorite (unit $\mathrm{Kg}$ ) and gabbro (unit Kgb). Found on Prince of Wales Island (Eberlein and others, 1983; Gehrels and Saleeby, 1986, 1987a) and on Chichagof Island (Loney and others, 1975; Johnson and Karl, 1985). As described above for the Cretaceous granodiorite unit $(\mathrm{Kg})$, some rocks in this unit may be of Late Jurassic or of Silurian or Ordovician age

$\mathrm{Kgb}$ Gabbro (Cretaceous)—Primarily clinopyroxene (generally augite) \pm hornblende \pm biotite \pm olivine gabbro, leucogabbro, and subordinate norite, syenite, and pyroxenite. Found on Prince of Wales Island (Eberlein and others, 1983), Kuiu Island (Brew and others, 1984), and Chichagof Island where it is associated with Early Cretaceous granodiorite (unit $\mathrm{Kg}$ ) and diorite (unit $\mathrm{Kd}$ ) (Loney and others, 1975; Johnson and Karl,
1985). As described above for the Cretaceous granodiorite unit $(\mathrm{Kg})$, some rocks in this unit may be of Late Jurassic or of Silurian or Ordovician age

KJd Diorite (Cretaceous and Jurassic)Metamorphosed and moderately deformed diorite and subordinate quartz diorite and gabbro on Annette Island, Revillagigedo Island, and mainland to northwest (Berg and others, 1978, 1988). A small quartz diorite body near northern Annette Island yielded a Cretaceous potassium-argon apparent age; the other bodies are undated. We have assigned a Cretaceous and Jurassic age on the basis of our interpretation that rocks in unit are genetically related to Cretaceous and Jurassic volcanic (KJv) and sedimentary $(\mathrm{KJ} s)$ rocks

KJgb Gabbro (Cretaceous and Jurassic)-Twopyroxene gabbro and subordinate hornblende \pm biotite gabbro and diorite. These intrusive rocks generally found adjacent to and intruded by Early Cretaceous zoned ultramafic bodies (unit Kum). Found on mainland near Myers Chuck (Ruckmick and Noble, 1959; Eberlein and others, 1983). We have assigned a Cretaceous and Jurassic age on the basis of our interpretation that rocks in unit are genetically related to Cretaceous and Jurassic volcanic (KJv) and sedimentary rocks (KJs)

Jgr Granite (Jurassic)—Peralkaline aegerine and arfvedsonite granite (Bokan Mountain Granite) on southern Prince of Wales Island (MacKevett, 1963) that yielded Jurassic potassium-argon (Lanphere and others, 1964), uranium-lead (zircon) (Saint-Andre and others, 1983), and rubidium-strontium (Armstrong, 1985) apparent ages; and an undated body of nepheline-eudialyte-bearing syenite north of the Bokan Mountain Granite (Eberlein and others, 1983) suspected to be of Jurassic age

Jt Tonalite (Jurassic)-Biotite and hornblende tonalite and quartz diorite on Chichagof Island that yielded a Middle Jurassic potassium-argon (hornblende) apparent age (Loney and others, 1975)

Jkd Diorite (Jurassic and (or) Triassic)Hornblende and biotite diorite (Jualin Diorite) along east shore of Lynn Canal (Knopf, 1911; Redman, 1984a). The diorite produces a hornfelsic aureole in adjacent metasedimentary and metavolcanic rocks of probable Triassic or Permian age (unit KPsv) and is overlain unconformably by less metamorphosed Cretaceous and Jurassic sedimentary rocks (KJs) (Redman, 1984a). These relations suggest an emplacement age of Jurassic and (or) Triassic for the Jualin 
Diorite. As discussed above for Cretaceous to Permian sedimentary and volcanic rocks (KPsv), these relations also suggest that some rocks in the Cretaceous to Permian units (units KPsv, KPs, KPv, KPsvc) were metamorphosed and deformed prior to deposition of the Cretaceous and Jurassic strata (units KJs, KJv, and KJsv)

$\mathrm{kgb}$ Gabbro (Triassic)-Two-pyroxene gabbro on Duke Island (Irvine, 1974) and Percy Islands (Berg and others, 1978, 1988) that yields a Late Triassic uranium-lead (zircon) apparent age (Gehrels and others, 1987)

$\mathrm{kg}$ Granodiorite (Triassic)-Hornblende and biotite granodiorite and minor quartz diorite (part of Texas Creek Granodiorite of Berg and others, 1977) northeast of Revillagigedo Island (Berg and others, 1978, 1988) that yielded a latest Triassic potassium-argon (hornblende) apparent age (Smith and Diggles, 1981)

PPsy Syenite (Permian and (or) Pennsylvanian)Syenite on Sukkwan Island that contains biotite \pm amphibole \pm aegerine \pm augite and yielded potassium-argon apparent ages of Early Permian (hornblende) and Late Pennsylvanian (biotite) (Eberlein and others, 1983). This body is apparently correlative with syenitic plutons in the Saint Elias mountains region of southern Alaska that yield a Late Pennsylvanian potassium-argon (hornblende) apparent age (MacKevett and others, 1986)

Sst Syenite and trondhjemite (Silurian)-Consists of (1) leucocratic biotite \pm aegerine \pm arfvedsonite \pm garnet syenite and subordinate leucodiorite on southern Prince of Wales Island (Gehrels and Saleeby, 1986, 1987a); (2) biotite and hornblende trondhjemite on Annette and Gravina Islands and mainland to southeast (Gehrels and others, 1987); and (3) undivided biotite and (or) hornblende syenite and trondhjemite on Chichagof Island (Loney and others, 1975). Silurian age indicated by a minimum potassium-argon apparent age on Chichagof Island (Lanphere and others, 1965) and by uraninum-lead (zircon) apparent ages of rocks from Annette, Gravina, and Prince of Wales Islands and mainland to southeast (Gehrels and Saleeby, 1987a, b; Gehrels and others, 1987)

SOum Ultramafic rocks (Silurian and Ordovician) Pyroxenite, hornblendite, and related ultramafic rocks on southern Prince of Wales Island (MacKevett, 1963; Gehrels and Saleeby, 1986, 1987a), on southern Dall Island (G.E. Gehrels, unpub. data, 1984), and on east-central Prince of Wales Island (Loney and others, 1987). Ultramafic rocks on southern Prince of Wales Island are

interpreted to be Silurian on the basis of gradational relations with syenitic rocks of Silurian age (Sst). The intrusive body on Dall Island yielded a Late Ordovician potassiumargon (hornblende) apparent age (M.A. Lanphere, written commun., 1984). An Early Silurian potassium-argon (biotite) apparent age has been determined on the body on east-central Prince of Wales Island (Loney and others, 1987)

$\mathrm{SOq}$

Ogb

$€ d g$

\section{REFERENCES CITED}

Armstrong, R.L., 1985, Rb-Sr dating of the Bokan Mountain granite complex and its country rocks: Canadian Journal of Earth Sciences, v. 22, p. 1233-1236. 
Barker, Fred, 1957, Geology of the Juneau B-3 quadrangle, Alaska: U.S. Geological Survey Geologic Quadrangle Map GQ-100, scale 1:63,360, 1 sheet.

Barker, Fred, Arth, J.G., and Stern, T.W., 1986, Evolution of the Coast Batholith along the Skagway traverse, Alaska and British Columbia: American Mineralogist, v. 71, p. 632-643.

Berg, H.C., 1982, The Alaska Mineral Resource Assessment Program: Guide to information about the geology and mineral resources of the Ketchikan and Prince Rupert quadrangles, southeastern Alaska: U.S. Geological Survey Circular 855, 24 p.

Berg, H.C., Elliott, R.L., and Koch, R.D., 1988, Geologic map of the Ketchikan and Prince Rupert quadrangles, southeastern Alaska: U.S. Geological Survey Miscellaneous Investigations Series I-1807, scale 1:250,000, 1 sheet.

Berg, H.C., Elliott, R.L., Smith, J.G., and Koch, R.D., 1978, Geologic map of the Ketchikan and Prince Rupert quadrangles, Alaska: U.S. Geological Survey Open-File Report 78-73A, scale 1:250,000, 1 sheet.

Berg, H.C., Elliott, R.L., Smith, J.G., Pittman, T.L., and Kimball, A.L., 1977, Mineral resources of the Granite Fiords Wilderness Study Area, Alaska: U.S. Geological Survey Bulletin 1403, 151 p.

Berg, H.C., and Grybeck, Donald, 1980, Upper Triassic volcanogenic $\mathrm{Zn}-\mathrm{Pb}-\mathrm{Ag}$ (-Cu-Au)-barite mineral deposits near Petersburg, Alaska: U.S. Geological Survey Open-File Report 80-527, 9 p.

Berg, H.C., Jones, D.L., and Richter, D.H., 1972, Gravina-Nutzotin belt-significance of an upper Mesozoic sedimentary and volcanic sequence in southern and southeastern Alaska, in Geological Survey Research 1972: U.S. Geological Survey Professional Paper 800-D, p. D1-D24.

Brew, D.A., 1982, Interpretation of the heterogeneous rocks in the Duncan Canal area as a Cretaceous melange, in Geological Survey Research 1981: U.S. Geological Survey Professional Paper 1275, p. 90.

Brew, D.A., and Ford, A.B., 1977, Preliminary geologic and metamorphic-isograd map of the Juneau B-1 quadrangle, Alaska: U.S. Geological Survey Miscellaneous Field Studies Map MF-846, scale 1:31,680, 1 sheet.

1978, Megalineament in southeastern Alaska marks southwest edge of Coast Range batholithic complex: Canadian Journal of Earth Sciences, v. 15 , no. 11 , p. $1763-1772$.

1981, The Coast plutonic complex sill, southeastern Alaska, in Albert, N.R.D., and Hudson, T.L., eds., The U.S. Geological Survey in Alaska Accomplishments during 1980: U.S. Geological Survey Circular 823-B, p. B96-B98.

1985, Preliminary reconnaissance geologic map of the Juneau, Taku River, Atlin, and Skagway quadrangles, southeastern Alaska: U.S. Geological Survey Open-File Report 85-395, scale 1:250,000, $23 \mathrm{p}$.

Brew, D.A., Ford, A.B., and Garwin, S.L., 1985, Fos- siliferous Middle and (or) Upper Triassic rocks within the Coast plutonic-metamorphic complex southeast of Skagway, in Bartsch-Winkler, Susan, ed., The U.S. Geological Survey in Alaska: Accomplishments during 1984: U.S. Geological Survey Circu$\operatorname{lar} 967$, p. 86-89.

Brew, D.A., and Grybeck, Donald, 1984, Geology of the Tracy Arm-Fords Terror Wilderness Study Area and vicinity, Alaska: U.S. Geological Survey Bulletin 1525-A, p. 21-52, scale 1:125,000.

Brew, D.A., Johnson, B.R., Grybeck, Donald, Griscom, Andrew, and Barnes, D.F., 1978, Mineral resources of the Glacier Bay National Monument Wilderness Study Area, Alaska: U.S. Geological Survey OpenFile Report 78-494, 670 p., scale 1:125,000.

Brew, D.A., Karl, S.M., and Tobey, E.F., 1985, Re-interpretation of age of Kuiu-Etolin belt of volcanic rocks, Kupreanof Island, southeastern Alaska, in Bartsch-Winkler, Susan, and Reed, K.M., The U.S. Geological Survey in Alaska, Accomplishments during 1983: U.S. Geological Survey Circular 945, p. $86-88$.

Brew, D.A., and Morrell, R.P., 1979, Correlation of Sitka Graywacke, unnamed rocks of the Fairweather Range, and Valdez Group, southeastern and south-central Alaska, in Johnson, K.M., and Williams, J.R., The U.S. Geological Survey in Alaska: Accomplishments during 1978: U.S. Geological Survey Circular 804-B, p. B123-B125.

Brew, D.A., Ovenshine, A.T., Karl, S.M., and Hunt, S.J., 1984, Preliminary reconnaissance geologic map of the Petersburg and parts of the Port Alexander and Sumdum 1:250,000 quadrangles, southeastern Alaska: U.S. Geological Survey Open-File Report 84-405, 43 p., scale 1:250,000, 2 sheets.

Buddington, A.F., and Chapin, Theodore, 1929, Geology and mineral deposits of southeastern Alaska: U.S. Geological Survey Bulletin 800, 398 p., scale 1:500,000.

Burrell, P.D., 1984, Map and table describing the Admiralty-Revillagigedo intrusive belt plutons in the Petersburg 1:250,000 quadrangle, southeastern Alaska: U.S. Geological Survey Open-File Report 84-171, 6 p., scale 1:250,000, 1 sheet.

Campbell, R.B., and Dodds, C.J., 1983, Geology of the Tatshenshini River map area, British Columbia: Geological Survey of Canada Open-File 926, scale $1: 125,000,1$ sheet.

Carter, Claire, 1977, Age of the Hood Bay Formation: U.S. Geological Survey Bulletin 1435-A, p. A117.

Clark, A.L., Berg, H.C., Grybeck, Donald, and Ovenshine, A.T., 1971, Reconnaissance geology and geochemistry of Forrester Island National Wildlife Refuge, Alaska: U.S. Geological Survey Open-File Report 465, 7 p.

Davis, Alice, and Plafker, George, 1985, Comparative geochemistry and petrology of Triassic basaltic rocks from the Taku terrane on the Chilkat Peninsula and Wrangellia: Canadian Journal of Earth Sciences, v. 22, p. 183-194.

Decker, J.E., 1980, Geology of a Cretaceous subduc- 
tion complex, western Chichagof Island, southeastern Alaska: Stanford, Calif., Stanford University, unpublished Ph.D. thesis, $134 \mathrm{p}$.

Decker, J.E., Nilsen, T.H., and Karl, S.M., 1979, Turbidite facies of the Sitka Graywacke, southeastern Alaska, in Johnson, K.M., and Williams, J.R., eds., The U.S. Geological Survey in Alaska: Accomplishments during 1978: U.S. Geological Survey Circular 804-B, p. B125-B128.

Decker, J.E., and Plafker, George, 1982, Correlation of rocks in the Tarr Inlet suture zone with the Kelp Bay Group, in Coonrad, W.L., ed., The U.S. Geological Survey in Alaska: Accomplishments during 1980: U.S. Geological Survey Circular 844, p. 119-123.

Decker J.E., Wilson, F.H., and Turner, D.L., 1980, Mid-Cretaceous subduction event in southeastern Alaska [abs.]: Geological Society of America Abstracts with Programs, v. 12, no. 3, p. 103.

Douglas, B.J., 1986, Deformational history of an outlier of metasedimentary rocks, Coast plutonic complex, British Columbia, Canada: Canadian Journal of Earth Sciences, v. 23, p. 813-826.

Dutro, J.T., Jr., Armstrong, A.K., Douglass, R.C., and Mamet, B.L., 1981, Carboniferous biostratigraphy, southeastern Alaska, in Albert, N.R.D., and Hudson, Travis, eds., The U.S. Geological Survey in Alaska: Accomplishments during 1979: U.S. Geological Survey Circular 823-B, p. B94-B96.

Eberlein, G.D., Churkin, Michael, Jr., Carter, Claire, Berg, H.C., and Ovenshine, A.T., 1983, Geology of the Craig quadrangle, Alaska: U.S. Geological Survey Open-File Report 83-91, 26 p., scale 1:250,000.

Elliott, R.L., and Koch, R.D., 1981, Mines, prospects, and selected metalliferous mineral occurrences in the Bradfield Canal quadrangle, Alaska: U.S. Geological Survey Open-File report 81-728B, 23 p., scale 1:250,000, 1 sheet.

Elliott, R.L., Koch, R.D., and Robinson, S.W., 1981, Age of basalt flows in the Blue River valley, Bradfield Canal quadrangle, in Albert, N.R.D., and Hudson Travis, eds., The U.S. Geological Survey in Alaska: Accomplishments during 1979: U.S. Geological Survey Circular 823-B, p. B115-B116.

Forbes, R.B., and Engels, J.C., $1970, \mathrm{~K}^{40} / \mathrm{Ar}^{40}$ age relations of the Coast Range batholith and related rocks of the Juneau ice field area: Geological Society of America Bulletin, v. 81, p. 579-584.

Ford, A.B., and Brew, D.A., 1973, Preliminary geologic and metamorphic-isograd map of the Juneau B-2 quadrangle, Alaska: U.S. Geological Survey Miscellaneous Field Studies Map MF-527, scale $1: 31,680,1$ sheet.

1977, Preliminary geologic and metamorphicisograd map of the northern parts of the Juneau A1 and A-2 quadrangles, Alaska: U.S. Geological Survey Miscellaneous Field Studies Map MF-847, scale $1: 31,680,1$ sheet.

Gehrels, G.E., Brew, D.A., and Saleeby, J.B., 1984, Progress report on $\mathrm{U} / \mathrm{Pb}$ (zircon) geochronologic studies in the Coast plutonic-metamorphic complex east of Juneau, southeastern Alaska, in BartschWinkler, S., and Reed, K.L., eds., The U.S. Geological Survey in Alaska: Accomplishments during 1982: U.S. Geological Survey Circular 939 , p. 100-102.

Gehrels, G.E., Dodds, C.J., and Campbell, R.B., 1986, Upper Triassic rocks of the Alexander terrane, SE Alaska and the Saint Elias Mountains of B.C. and Yukon [abs.]: Geological Society of America Abstracts with Programs, v. 18, p. 109.

Gehrels, G. E., and Saleeby, J.B., 1986, Geologic map of southern Prince of Wales Island, southeastern Alaska: U.S. Geological Survey Open-File Report 86-275, scale 1:63,360, 1 sheet.

1987a, Geology of southern Prince of Wales Island, southeastern Alaska: Geological Society of America Bulletin, v. 98, p. 123-137.

1987b, Geologic framework, tectonic evolution, and displacement history of the Alexander terrane: Tectonics, v. 6, p. 151-173.

Gehrels, G.E., Saleeby, J.B., and Berg, H.C., 1987, Geology of Annette, Gravina, and Duke Islands, southeastern Alaska: Canadian Journal of Earth Sciences, v. 24, p. 866-881.

Grybeck, Donald, Brew, D.A., Johnson, B. R., and Nutt, C.J., 1977, Ultramafic rocks in part of the Coast Range batholithic complex, southeastern Alaska, in Blean, K.M., ed., The U.S. Geological Survey in Alaska: Accomplishments during 1976: U.S. Geological Survey Circular 751-B, p. B82B85.

Herreid, Gordon, Bundtzen, T.K., and Turner, D.L., 1978, Geology and geochemistry of the Craig A-2 quadrangle and vicinity, Prince of Wales Island, southeastern Alaska: Alaska Division of Geological and Geophysical Surveys Geologic Report 48, 49 p., scale 1:40,000.

Hill, M.L., 1985a, The Coast plutonic complex near Terrace, B.C.: A metamorphosed western extension of Stikinia: Geological Society of America Abstracts with Programs, v. 17, no. 6, p. 362.

1985b, Remarkable fossil locality: Crinoid stems from migmatite of the Coast plutonic complex, British Columbia: Geology, v. 13, p. $825-$ 826.

Himmelberg, G.R., Loney, R.A., and Craig, J.T., 1986, Petrogenesis of the ultramafic complex at the Blaske Islands, southeastern Alaska: U.S. Geological Survey Bulletin 1662, 14 p.

Hudson, Travis Plafker, George, and Dixon, Kirk, 1982, Horizontal offset history of the Chatham Strait fault, in Coonrad, W.L., ed., The U.S. Geological Survey in Alaska: Accomplishments during 1980: U.S. Geological Survey Circular 844, p. 128-132.

Hutchison, W.W., 1982, Geology of the Prince RupertSkeena map area, British Columbia: Geological Survey of Canada Memoir 394, 116 p., scale $1: 250,000$.

Hutchison, W.W., Okulitch, A.V., and Berg, H.C., 
1979, Geologic map of the Skeena River area, British Columbia and southeastern Alaska: Geological Survey of Canada Map 1385A, scale $1: 1,000,000$.

Irvine, T.N., 1967, The Duke Island ultramafic complex, southeastern Alaska, in Wyllie, P.J., ed., Ultramafic and related rocks: New York, John Wiley and Sons, Inc., p. 84-97.

1973, Bridget Cove volcanics, Juneau area, Alaska: possible parental magma of Alaskan-type ultramafic complexes: Carnegie Institute of Washington Yearbook 72, p. 478-491.

1974, Petrology of the Duke Island ultramafic complex, southeastern Alaska: Geological Society of America Memoir 138, 240 p.

Johnson, B.R., and Karl, S.M., 1985, Geologic map of western Chichagof and Yakobi Islands, southeastern Alaska: U.S. Geological Survey Miscellaneous Investigations Map 1-1506, scale 1:125,000, 1 sheet, $15 \mathrm{p}$.

Jones, D.L., Silberling, N.J., and Hillhouse, John, 1977, Wrangellia-a displaced terrane in northwestern North America: Canadian Journal of Earth Sciences v. 14, p. 2565-2577.

Jones, D.L., Berg, H.C., Coney, P.J., and Harris, Anita, 1981, Structural and stratigraphic significance of Upper Devonian and Mississippian fossils from the Cannery Formation, Kupreanof Island, southeastern Alaska, in Albert, N.R.D., and Hudson, Travis, eds., The U.S. Geological Survey in Alaska: Accomplishments during 1979: U.S. Geological Survey Circular 823-B, p. B109-B112.

Karl, S.M., 1984, Recognition of the Burnt Island Conglomerate on the Screen Islands, southeastern Alaska, in Coonrad, W.L., and Elliott, R.L., eds., The U.S. Geological Survey in Alaska: Accomplishments during 1981: U.S. Geological Survey Circular 868, p. 115-117.

Karl, S.M., Decker, J.E., and Johnson, B.R., 1982, Discrimination of Wrangellia and the Chugach terrane in the Kelp Bay Group on Chichagof and Baranof Islands, southeastern Alaska, in Coonrad, W.L., ed., The U.S. Geological Survey in Alaska: Accomplishments during 1980: U.S. Geological Survey Circular 844, p. 124-128.

Knopf, Adolph, 1911, Geology of the Berners Bay region, Alaska: U.S. Geological Survey Bulletin 446 , $58 \mathrm{p}$.

1912, The Eagle River region, southeastern Alaska: U.S. Geological Survey Bulletin 502, 61 p.

Koch, R.D., and Elliott, R.L., 1984, Lake Oligocene gabbro near Ketchikan, southeastern Alaska, in Coonrad, W.L., and Elliott, R.L., eds., The U.S. Geological Survey in Alaska: Accomplishments during 1981: U.S. Geological Survey Circular 868, p. 126-128.

Lanphere, M.A., and Eberlein, G.D., 1966, Potassiumargon ages of magnetite-bearing ultramafic complexes in southeastern Alaska [abs.]: Geological Society of America Special Paper 87, p. 94.

Lanphere, M.A., Loney, R.A., and Brew, D.A., 1965,
Potassium-argon ages of some plutonic rocks, Tenakee area, Chichagof Island, southeastern Alaska: U.S. Geological Survey Professional Paper 525-B, p. B108-B111.

Lanphere, M.A., MacKevett, E.M., and Stern, T.W., 1964, Potassium-argon and lead-alpha ages of plutonic rocks, Bokan Mountain area, Alaska: Science, v. 145, p. 705-707.

Lathram, E.H., Loney, R.A., Condon, W.H., and Berg, H.C., 1959, Progress map of the geology of the Juneau quadrangle, Alaska: U.S. Geological Survey Miscellaneous Geological Investigations Map I303, scale 1:250,000, 1 sheet.

Lathram, E.H., Pomeroy, J.S., Berg, H.C., and Loney, R.A., 1965, Reconnaissance geology of Admiralty Island, Alaska: U.S. Geological Survey Bulletin 1181-R, p. R1-R48.

Loney, R.A., Brew, D.A., Muffler, L.J.P., and Pomeroy, J.S., 1975, Reconnaissance geology of Chichagof, Baranof, and Kruzof Islands, southeastern Alaska: U.S. Geological Survey Professional Paper 792, $105 \mathrm{p}$.

Loney, R.A., and Himmelberg, G.R., 1983, Structure and petrology of the La Perouse gabbro intrusion, Fairweather Range, southeastern Alaska: Journal of Petrology, v. 24, p. 377-423.

Loney, R.A., Himmelberg, G.R., and Shew, Nora, 1987, Salt Chuck palladium-bearing ultramafic body, Prince of Wales Island, in Hamilton, T.D., and Galloway, J.P., eds., Geologic Studies in Alaska by the U.S. Geological Survey during 1986: U.S. Geological Survey Circular 998, p. 126-127.

MacKevett, E.M., Jr., 1963, Geology and ore deposits of the Bokan Mountain uranium-thorium area, southeastern Alaska: U.S. Geological Survey Bulletin $1154,125 \mathrm{p}$.

MacKevett, E.M., Jr., Gardner, M.C., Bergman, S.C., Cushing, G., and McClelland, W.C., 1986, Geological evidence for Late Pennsylvanian juxtaposition of Wrangellia and the Alexander terrane, Alaska [abs.]: Geological Society of America Abstracts with Programs, v. 18 , no. 2, p. 128.

MacKevett, E.M., Jr., Robertson, E.C., and Winkler, G.R., 1974, Geology of the Skagway B-3, and B-4 quadrangles, southeastern Alaska: U.S. Geological Survey Professional Paper 832, 33 p.

Marincovich, Louie, Jr., 1979, Miocene mollusks of the Topsy Formation, Lituya District, Gulf of Alaska Tertiary Province, Alaska: U.S. Geological Survey Professional Paper 1125-C, p. C1-C14.

Martin, G.C., 1926, The Mesozoic stratigraphy of Alaska: U.S. Geological Survey Bulletin 77, 493 p.

McClelland, W.C., and Gehrels, G.E., 1987, Analysis of a major shear zone in Duncan Canal, southeastern Alaska: [abs.] Geological Society of America Abstracts with Programs, v. 19, p. 430.

Muffler, L.J.P., 1967, Stratigraphy of the Keku Islets and neighboring parts of Kuiu and Kupreanof Islands, southeastern Alaska: U.S. Geological Survey Bulletin 1241-C, 52 p.

North American Commission on Stratigraphic Nomen- 
clature, 1983, North American Stratigraphic Code: American Association of Petroleum Geologists Bulletin, v. 67 , no. 5 , p. 841-875.

Ovenshine, A.T., 1975, Tidal origin of parts of the Karheen Formation (Lower Devonian), southeastern Alaska, in Ginsburg, R.N., ed., Tidal deposits: a casebook of recent examples and fossil counterparts: Berlin, Springer-Verlag, p. 127-133.

Palmer, A.R., 1983, Decade of North American Geology Geologic Time Scale: Geology, v. 11, p. 503504.

Plafker, George, and Addicott, W.O., 1976, Glaciomarine deposits of Miocene through Holocene age in the Yakataga Formation along the Gulf of Alaska margin, in Miller, T.P., ed., Symposium on recent and ancient sedimentary environments in Alaska: Anchorage Geological Society, Anchorage, Alaska, 1976, p. Q1-Q23.

Plafker, George, and Campbell, R.B., 1979, The Border Ranges fault in the Saint Elias Mountains, in Johnson, K.M., and Williams, J.R., The U.S. Geological Survey in Alaska: Accomplishments during 1978: U.S. Geological Survey Circular 804 B, p. B102-B104.

Plafker, George, and Hudson, Travis, 1980, Regional implications of Upper Triassic metavolcanic and metasedimentary rocks on the Chilkat Peninsula, southeastern Alaska: Canadian Journal of Earth Sciences, v. 17, p. 681-689.

Plafker, George, Jones, D.L., Hudson, Travis, and Berg, H.C., 1976, The Border Ranges fault system in the Saint Elias Mountains and Alexander Archipelago, in Cobb, E.H., ed., The U.S. Geological Survey in Alaska: Accomplishments during 1975: U.S. Geological Survey Circular 733, p. 14-16.

Plafker, George, Jones, D.L., and Pessagno, E.A., Jr., 1977, A Cretaceous accretionary flysch and melange terrane along the Gulf of Alaska margin, in Blean, K.M., ed., The U.S. Geological Survey in Alaska: Accomplishments during 1976: U.S. Geological Survey Circular 751-B, p. B41-B44.

Redman, Earl, 1981, The Keete Inlet thrust fault, Prince of Wales Island: Alaska Division of Geological and Geophysical Surveys Report 73, p. 17-18.

1984a, An unconformity with associated conglomeratic sediments in Berners Bay area of southeast Alaska: Alaska Division of Geological and Geophysical Surveys Professional Report 86, p. $1-4$.

1984b, Reconnaissance geology of the Mt. Henry Clay area, Skagway B-4 quadrangle, Alaska, in Still, J.C., Stratiform massive sulfide deposits in the Mt. Henry Clay area, southeast Alaska: U.S. Bureau of Mines Open-File Report 118-84, scale 1:40,000, 4 sheets, $34 \mathrm{p}$.

Redman, E.C., Gilbert, W.G., Jones, B.K., Rosencrans, D., and Hickok, B.D., 1985, Preliminary bedrockgeologic map of the Skagway B-4 quadrangle, Alaska: Alaska Division of Geological and Geophysical Surveys Report of Investigations 856 , scale 1:40,000, 1 sheet.
Redman, Earl, Retherford, R.M., and Hickok, B.D., 1984, Geology and geochemistry of the Skagway B-2 quadrangle, southeastern Alaska: Alaska Division of Geological and Geophysical Surveys Report of Investigations RI 84-31.

Reed, J.C., and Coats, R.R., 1941, Geology and ore deposits of the Chichagof mining district, Alaska: U.S. Geological Survey Bulletin 929, 148 p.

Rossman, D.L., 1963, Geology of the eastern part of the Mount Fairweather quadrangle, Glacier Bay, Alaska: U.S. Geological Survey Bulletin 1121-K, p. K1-K57.

Rubin, C.M., and Saleeby, J.B., 1987, The inner boundary zone of the Alexander terrane, southern SE Alaska-A newly discovered thrust belt [abs.]: Geological Society of America Abstracts with Programs, v. 19 , no. 6 , p. 445 .

Ruckmick, J.C., and Noble, J.A., 1959, Origin of the ultramafic complex at Union Bay, southeastern Alaska: Geological Society of America Bulletin, v. 70, p. 981-1017.

Saleeby, J.B., Gehrels, G.E., Eberlein, G.D., and Berg, H.C., 1984, Progress in lead/uranium zircon studies of Lower Paleozoic rocks in the southern Alexander terrane, in Coonrad, W.L., and Elliott, R.L., eds., The U.S. Geological Survey in Alaska: Accomplishments during 1981: U.S. Geological Survey Circular 868, p. 110-113.

Saint-Andre, Bruno de, Lancelot, J.R., and Collot, Bernard, 1983, U-Pb geochronology of the Bokan Mountain peralkaline granite, southeastern Alaska: Canadian Journal of Earth Sciences, v. 20, p. 236245.

Savage, N.M., 1981, Lower Devonian conodonts from Kasaan Island, southeastern Alaska: Journal of Paleontology, v. 55, p. 848-852.

Savage, N.M., and Gehrels, G.E., 1984, Early Devonian conodonts from Prince of Wales Island, southeastern Alaska: Canadian Journal of Earth Sciences, v. 21, p. 1415-1425.

Silberling, N.J., Wardlaw, B.R., and Berg, H.C., 1982 , New paleontologic age determinations from the Taku terrane, Ketchikan area, southeastern Alaska, in Coonrad, W.L., ed., The U.S. Geological Survey in Alaska: Accomplishments during 1980: U.S. Geological Survey Circular 844, p. 117-119.

Smith, J.G., and Diggles, M.F., 1981, Potassium-argon determinations in the Ketchikan and Prince Ruppert quadrangles, southeastern Alaska: U.S. Geological Survey Open-File Report 78-73N.

Smith, J.G., Stern, T.W., and Arth, J.G., 1979, Isotopic ages indicate multiple episodes of plutonism and metamorphism in the Coast Mountains near Ketchikan, Alaska [abs.]: Geological Society of America Abstracts with programs, v. 11, no. 7, p. 519.

Sonnevil, R.A., 1981, The Chillkat-Prince of Wales plutonic province, southeastern Alaska, in Albert, N.R.D., and Hudson, Travis, eds., The U.S. Geological Survey in Alaska: Accomplishments during 1979: U.S. Geological Survey Circular 823B, p. B112-B115. 
Souther, J.G., 1971, Geology and mineral deposits of the Tulsequah map area, British Columbia: Geological Survey of Canada Memoir 362, 84 p.

Souther, J.G., Brew, D.A., and Okulitch, A.V., 1979, Geologic map of the Iskut River area, British Columbia and southeastern Alaska: Geological Survey of Canada Map 1418A, scale 1:1,000,000.

Streckheisen, A., 1976, To each plutonic rock its proper name: Earth Science Reviews, v. 12, p. 1-33.

Sutter, J.F., and Crawford, M.L., 1985, timing of metamorphism and uplift in the vicinity of Prince Rupert, British Columbia, and Ketchikan, Alaska [abs.]: Geological Society of America Abstracts with Programs, v. 17 , no. 6, p. 411.

Taylor, H.P., Jr., 1967, The zoned ultramafic complexes of southeastern Alaska, in Wyllie, P.J., ed., Ultramafic and related rocks: New York, John Wiley and Sons, Inc., p. 96-118.
Turner, D.L., Herreid, Gordon, and Bundtzen, T.K., 1977, Geochronology of southern Prince of Wales Island: Alaska Division of Geological and Geophysical Surveys Geologic Report 55, p. 11-16.

Webster, J.H., 1984, Preliminary report on a large granitic body in the Coast Mountains, northeast Petersburg quadrangle, in Bartsch-Winkler, Susan, and Reed, K.M., eds., The U.S. Geological Survey in Alaska: Accomplishments during 1982: U.S. Geological Survey Circular 939, p. 116-118.

Werner, L.J., 1978, Metamorphic terrane, northern Coast Mountains west of Atlin Lake, British Columbia: Geological Survey of Canada Current Research, Paper 78-1A, p. 69-70.

Woodsworth, G.J., Crawford, M.L., and Hollister, L.S., 1983, Metamorphism and structure of the Coast plutonic complex and adjacent belts, Prince Rupert and Terrace areas, British Columbia: Geological Survey of Canada Field Trip Guide, no. 14, 62 p. 